\title{
Anti-Inflammatory Activity of Natural Products
}

\author{
Abdullatif Azab ${ }^{1}$, Ahmad Nassar ${ }^{2}$ and Abed N. Azab 2,3,* \\ 1 Institute of Applied Research, The Galilee Society, P.O. Box 437, 20200 Shefa-Amr, Israel; \\ abedazab@gal-soc.org \\ 2 Department of Clinical Biochemistry and Pharmacology, Faculty of Health Sciences, \\ Ben-Gurion University of the Negev, P.O. Box 653, 84105 Beer-Sheva, Israel; nassarah@post.bgu.ac.il \\ 3 Department of Nursing, Faculty of Health Sciences, Ben-Gurion University of the Negev, P.O. Box 653, \\ 84105 Beer-Sheva, Israel \\ * Correspondence: azab@bgu.ac.il; Tel.: +972-8-6479880; Fax: +972-8-6477683
}

Academic Editor: Norbert Latruffe

Received: 25 August 2016; Accepted: 28 September 2016; Published: 1 October 2016

\begin{abstract}
This article presents highlights of the published literature regarding the anti-inflammatory activities of natural products. Many review articles were published in this regard, however, most of them have presented this important issue from a regional, limited perspective. This paper summarizes the vast range of review and research articles that have reported on the anti-inflammatory effects of extracts and/or pure compounds derived from natural products. Moreover, this review pinpoints some interesting traditionally used medicinal plants that were not investigated yet.
\end{abstract}

Keywords: natural products; anti-inflammatory activity; plant extract; pure compounds

\section{Introduction}

Inflammation usually occurs when infectious microorganisms such as bacteria, viruses or fungi invade the body, reside in particular tissues and/or circulate in the blood [1-3]. Inflammation may also happen in response to processes such as tissue injury, cell death, cancer, ischemia and degeneration [1,4-9]. Mostly, both the innate immune response as well as the adaptive immune response are involved in the formation of inflammation $[1,5,9]$. The innate immune system is the foremost defense mechanism against invading microorganisms and cancer cells, involving the activity of various cells including macrophages, mast cells and dendritic cells. The adaptive immune systems involves the activity of more specialized cells such as $\mathrm{B}$ and $\mathrm{T}$ cells who are responsible for eradicating invading pathogens and cancer cells by producing specific receptors and antibodies.

Numerous inflammatory mediators are synthetized and secreted during inflammatory responses of different types. Inflammatory substances are usually divided to two main categories: pro- and anti-inflammatory mediators. Nevertheless, some mediators such as interleukin (IL)-12 possess both pro- and anti-inflammatory properties [10]. Among the inflammatory mediators and cellular pathways that have been extensively studied in association with human pathological conditions are cytokines (e.g., interferons, interleukins and tumor necrosis factor $\alpha$ ), chemokines (e.g., monocyte chemoattractant protein 1), eicosanoids (e.g., prostaglandins and leukotrienes) and the potent inflammation-modulating transcription factor nuclear factor $\mathrm{\kappa} B$.

Tumor necrosis factor (TNF)- $\alpha$ is an important pro-inflammatory cytokine which is secreted from various cells and exerts many cellular effects $[11,12]$. TNF- $\alpha$ has been associated with multiple illness states in humans, including immune and inflammatory diseases, cancer, psychiatric disorders, among others. Another cytokine which mostly exerts a pro-inflammatory activity is IL-1 $\alpha[13,14]$. It stimulates the secretion of pro-inflammatory cytokines such as IL-1 $\beta$ and TNF- $\alpha[13,14]$. However, IL- $1 \alpha$ has also been associated with anti-inflammatory activity. Similar to IL- $1 \alpha$, IL- 6 usually acts as a pro-inflammatory cytokine but it also has some anti-inflammatory effects. As mentioned 
above, the IL-12 family of cytokines (including IL-12, IL-23, IL-27 and IL-35) possess both pro- and anti-inflammatory functions $[10,15,16]$. On the other hand, IL-10 is a potent anti-inflammatory cytokine the activity of which impedes the action of many pro-inflammatory mediators [17-19]. By weakening and controlling the inflammatory response IL-10 helps to maintain tissue homeostasis and attenuates the damage that may result from an exaggerated inflammatory response [17-19].

Prostaglandin (PG) $\mathrm{E}_{2}$ is probably the most studied PG in association with human physiological and pathological conditions [20]. It has various physiological roles including regulation of normal body temperature, gastric mucosal integrity, renal blood flow and the function of female reproductive system. On the other hand, alterations in $\mathrm{PGE}_{2}$ activity are associated with pathological conditions such as inflammatory diseases, abnormal changes in body temperature, colorectal cancer, among others. The pathway of PGs synthesis starts with generation of arachidonic acid from cell membrane phospholipids by phospholipase A2 (PLA2). Then, arachidonic acid is converted to PGs by the enzyme cycloogygenase (COX) [20]. Among the three known COX isoforms (COX-1, COX-2 and COX-3), the inducible enzyme COX-2 is recognized as the most active during inflammatory processes. Leukotrienes (LTs) such as $\mathrm{LTB}_{4}$ were also linked to human illness states including inflammation, asthma and depression [21-23]. LTs are produced by the enzyme 5-lipooxygenase (5-LOX) [22]. Another enzyme that is highly associated with inflammatory conditions is nitric oxide synthase (NOS) which produces nitric oxide (NO) [24]. Similar to COX-2, inducible NOS (iNOS) is the most pro-inflammatory NOS isoform.

The transcription factor nuclear factor $\kappa \mathrm{B}(\mathrm{NF} \kappa \mathrm{B})$ is a prominent regulator of immune and inflammatory responses and is highly involved in the pathophysiology of cancer [25-27]. In mammals, the NFKB machinery comprises several members (e.g., p50 and p65) which regulate both physiological and pathological processes $[25,26]$. At resting (un-stimulated) conditions NFKB resides in the cytoplasm [26]. Following activation by various infectious/inflammatory/mitogenic stimuli, NFkB proteins translocate to the nucleus and induce transcription of inflammatory-associated genes [26,27].

The practice of using plants, their parts or extracts as anti-inflammatory compounds is known since antiquity. For example, concentrated, viscous aqueous extract of ripe carob (Ceratonia siliqua L.) has been used for decades in Arab folk medicine, especially for treating mouth inflammations [28]. The use of plants or plant products for medicinal purposes was mostly documented in books and, lately, in an enormous number of websites (where the reliability of some of these websites must be examined carefully). In the last decades, hundreds of research and review articles were published regarding the anti-inflammatory activities of plants. In this review we introduce some highlights of the literature published mainly during the last three decades, with a few references to earlier reports.

\section{Review Articles of Natural Non-Plant Materials}

As mentioned above, dozens of review articles have been published in the last few decades. Interestingly, a notable number of them were published by scholars from India, a country with a well rooted traditional plant medicine and a vast diversity of medicinal plants. Our summary here focuses on some of these reviews, but also includes articles from other parts of the world in order to provide a wider view. This part includes review articles which summarize the anti-inflammatory activities of non-plant natural products which exist in mushrooms and honey. Mushrooms and honey traditional therapies are very well established in most cultures. Moreover, mushrooms/honey mixtures with other plant materials (including various extracts) were used in folk medicines since ancient times.

One of the early articles that introduced the anti-inflammatory activities of mushrooms and some of their compounds was published by Lindequist et al. in 2005 [29]. Four different mushroom species were reviewed: Phellinus linteus that is used in traditional medicines of cultures of East Asia, Ganoderma lucidum (Lingzhi mushroom) which also has a long history of medicinal use in China, the widespread Pleurotus pulmonarius (subtropical forests) and the edible Grifola frondosa. Some biologically active compounds were extracted from each of these mushrooms. For example, eight different triterpenoid ganoderic acids were isolated from G. lucidum, but only four of them exerted 
anti-inflammatory activity (Figure 1A shows one of these compounds). From G. frondosa, an ergosterol oxidation product active as an anti-inflammatory agent was isolated (Figure 1B).

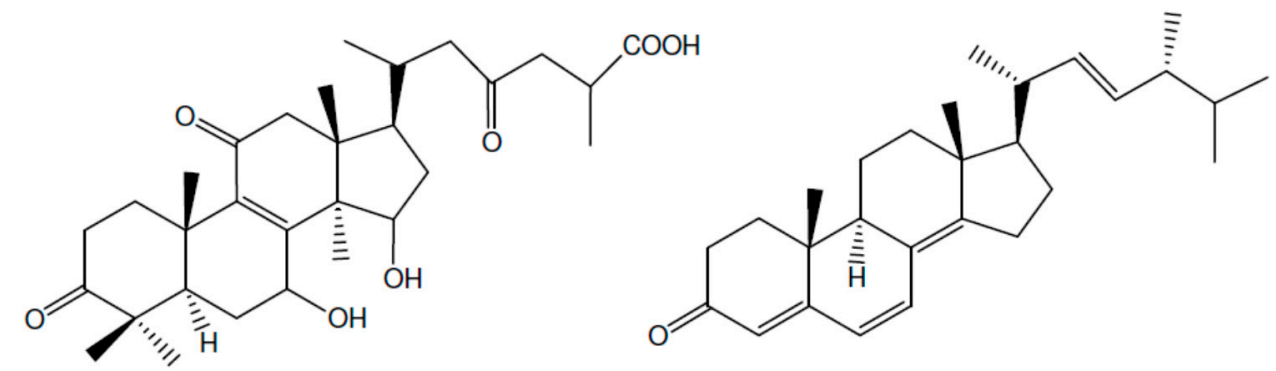

Figure 1. Structures of ganoderic acid A (A) and ergosta-4-6-8(14),22-tetraen-3-one (B).

An excellent, comprehensive review of anti-inflammatory activities of mushrooms was published by Elsayed and his colleagues in 2014 [30]. This article provides detailed, systematic information about a large number of mushroom species, many biologically active compounds, and importantly, suggested mechanisms of action. Among the most established anti-inflammatory effects of mushrooms that were reported in this article were: reduction of IL-1 $\beta$, IL-6, LTs, PGs and TNF- $\alpha$ levels, and, inhibition of COX-2, iNOS and NFKB activity [30]. The authors state that terpenoids are the largest group of anti-inflammatory compounds in mushrooms and presented some seven-membered, structurally interesting examples of these compounds (such as cyathins and related compounds, Figure 2).

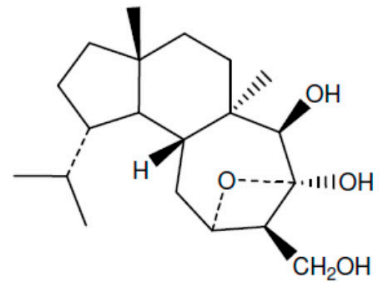

Cyathin 1

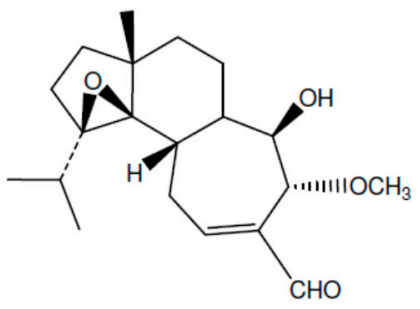

Cyathin 3

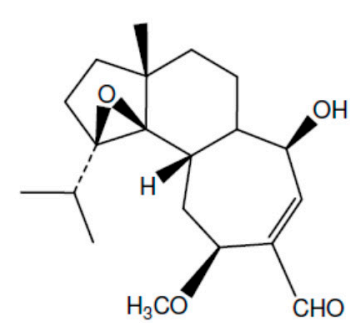

Cyathin 5

Figure 2. Structure of some cyathins isolated from mushrooms.

In their article, Elsayed et al. [30] addressed a study by Ngai et al. [31] which reported on the isolation of a 15 amino acids peptide from Agrocybe cylindrace which the authors named "agrocybin". Ngai et al. [31] reported that "agrocybin" exerted antifungal but not anti-inflammatory activity. However, for the sake of accuracy, it is important to mention that the name agrocybin also refers to a different compound (not a peptide), reported by Rosa and his colleagues [32] who isolated it from another Agrocybe species, A. perfecta. To the best of our knowledge, this compound also named agrocybin is a polyeyne amide [32,33], as shown in Figure 3.

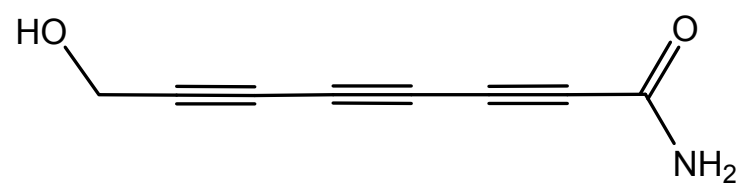

Figure 3. Structure of agrocybin.

The second source of non-plant, natural material with anti-inflammatory activity is honey. Since it is one of the most ancient nutritious foods and was mentioned in most holy religious texts, honey has been used for medicinal purposes since antiquity. Numerous review articles were published about 
the anti-inflammatory properties of honey. Almost all of these reviews focus on clinical evidence for the anti-inflammatory activity of honey but lack any reporting of active compounds. Moreover, most of the articles indicate that the precise mechanism underlying the anti-inflammatory activity of honey is unknown, although some present proposed mechanisms [34,35]. Mostly, honey was reported to have anti-inflammatory effects (such as reduction of TNF- $\alpha$ levels, attenuation of COX-2 activity, and inhibition of NFKB translocation to the nucleus) but pro-inflammatory actions were also indicated (e.g., elevation of NO production) [34,35].

\section{Review Articles on Natural Plant Materials}

Among the different biological activities of natural plant products that have been published until now, anti-inflammation is one of the most reported effects. Table 1 summarizes selected review articles which report on the anti-inflammatory properties of natural plant materials.

\section{Active Anti-Inflammatory Plant Extracts, Essential Oils, Juices and Powders}

Extracting plant materials is the first major step towards testing the biological activities of this plant. In doing so, there are many advantages and some disadvantages, comparing with isolation of pure active compounds. When a whole extract is used, there is a good chance for synergism between active components that might be lost when each of these components is isolated. Such synergism was discovered in several medicinal tests, including those for anti-inflammatory activity [36,37]. On the contrary, the mixture of different compounds together may also lead to inhibitory effects, namely, that one component may reduce the biological activity of the other. In line with this assumption, some studies have showed that the anti-inflammatory activity of pure compounds (such as amentoflavone, pseudohypericin, and hyperforin, isolated from extracts of Hypericum perforatum) is higher than that of the extracts [38]. In addition to plant extracts, essential oils [39,40], plant juices [41] and plant powders [42] are also widely used for medicinal purposes.

Solvent selection for extraction of plant materials is one of the most important factors in determining the potential activity of the extract, since the solvent polarity determines which compounds will be extracted and which will not. For example, it is unlikely that water (very polar) will extract the active anti-inflammatory compound monoterpene 1,8-cineole (Achillea millefolium) but will easily extract protocatechuic acid (Boswellia dalzielii), and vice versa for $n$-hexane (non-polar). Thus, in many cases of newly studied plants, various extracts are prepared with solvents that have a wide polarity range. Table 2 summarizes selected research articles which have reported on the anti-inflammatory activity of plant extracts.

There are several worth mentioning points regarding the information presented in Table 2. The plant Corchorus olitorius, known as Mulukhiyah in the Middle East, is one of the most important edible plants in this region. Despite this fact there are relatively very few reported studies regarding the medicinal properties of this plant. A study by Zakaria et al. [43] found that it exerted potent anti-inflammatory and antipyretic effects (Table 2). The title of the article by Islam et al. [44] states that "ethanol" was used to prepare extracts from mango (Mangifera indica) leaves, however, in the "Materials and Methods" section only methanol was mentioned as the extracting solvent. In the study by Li et al. [45] different extracts were prepared from hawthorn fruit (Crataegus pinnatifida Bunge var. typica Schneider). A first extract was prepared using 70\% methanol in water. Then, this extract was concentrated and extracted again with each of the following solvents: water, ethyl acetate, $n$-butanol and dichloromethane. Only the aqueous extract showed a significant anti-inflammatory activity. Of note, the most abundant hawthorn species in eastern Mediterranean region-Crataegus aronia-was never reported, although many of its medicinal activities are well acknowledged. A study by Abu-Gharbieh et al. [46] examined the anti-inflammatory effect of the aqueous extract of Micromeria fruticosa in mice. They reported a prominent reduction in carrageenan-induced paw edema. Moreover, pretreatment with the extract led to a significant decrease in gastric mucosal lesions induced by high-dose indomethacin, attesting for a gastro-protective effect of the extract. 
Table 1. Summary of selected review articles (2005-2016) reporting on the anti-inflammatory effects of plant products *.

\begin{tabular}{|c|c|c|c|c|}
\hline $\begin{array}{l}\text { Main Theme of } \\
\text { the Article }\end{array}$ & Major Method(s) of Testing & Major Active Materials/Compounds & Main Effects on Inflammation * & Ref. \\
\hline Brazilian plants & $\begin{array}{l}\text { Inflammation induction in rats and mice } \\
\text { (e.g., by carrageenan) }\end{array}$ & $\begin{array}{l}\text { Plants parts, various extracts, } \\
\text { chromatographic fractions }\end{array}$ & $\begin{array}{l}\text { Significant inhibition of COX and 5-LOX activity; reduction in } \\
\text { edema volume }\end{array}$ & [47] \\
\hline Plant-based foods & Plant-based food consumption in humans & $\begin{array}{l}\text { Carotenoids, flavonoids, phenolic acids, } \\
\text { monoterpenes, sulfides }\end{array}$ & $\begin{array}{l}\text { Reduction in C-reactive protein (CRP) and IL-6 levels; } \\
\text { inhibition of NFKB }\end{array}$ & [48] \\
\hline Plant natural products & $\begin{array}{l}\text { Various in vitro and in vivo models of } \\
\text { inflammation (e.g., lipopolysaccharide } \\
\text { [LPS]-induced) and cancer }\end{array}$ & $\begin{array}{l}\text { Polyphenols, capsaicin, curcumin, ascorbic acid, } \\
\text { indol-3-carbinol, geraniol, sulphoraphane, } \\
\text { gingerol, lycopene, deoxyelephantophin }\end{array}$ & $\begin{array}{l}\text { Significant reduction in cytokines levels; inhibition of COX-2, } \\
\text { iNOS, NFKB and STAT (signal transducers and activators of } \\
\text { transcription) activity }\end{array}$ & [49] \\
\hline Plant barks & $\begin{array}{l}\text { Various inflammation models in vivo } \\
\text { (e.g., carrageenan-induced paw edema) }\end{array}$ & $\begin{array}{l}\text { Various extracts, oleanolic acid, polyphenols, } \\
\text { coumarin, } \beta \text {-amyrin, ursolic acid, } \beta \text {-sitosterol }\end{array}$ & $\begin{array}{l}\text { Significant inhibition of COX and iNOS activity; attenuation of } \\
\text { paw edema }\end{array}$ & [50] \\
\hline $\begin{array}{l}\text { Medicinal plants } \\
\text { (General) }\end{array}$ & $\begin{array}{l}\text { Various inflammation models in vivo } \\
\text { (e.g., carrageenan-induced paw edema) }\end{array}$ & $\begin{array}{l}\text { Various extracts; ambrosanolide, betulinic acid, } \\
\text { ardisiaquinone G, polyphenols and others }\end{array}$ & $\begin{array}{l}\text { Inhibition of COX, iNOS, 5-LOX and PLA2 activity; attenuation } \\
\text { of paw edema }\end{array}$ & [51] \\
\hline $\begin{array}{l}\text { Herbal drugs } \\
\text { (medicinal plants) }\end{array}$ & $\begin{array}{l}\text { Various in vitro and in vivo (animals) } \\
\text { models of inflammation; clinical trials in } \\
\text { humans including safety and } \\
\text { efficacy measures }\end{array}$ & $\begin{array}{l}\text { Detailed compound families (e.g., alkaloids, } \\
\text { glycosides, terpenoids, resins, essential oils, fatty } \\
\text { acids, flavonoids, polysaccharides, phenolic } \\
\text { compounds, steroids, cannabinoids, glycoproteins) }\end{array}$ & $\begin{array}{l}\text { Significant reduction in cytokines, LTs, PGs and NO levels; } \\
\text { inhibition of COX, iNOS, 5-LOX, PLA2 and NFkB activity; in } \\
\text { humans: analgesic effects in different pain states, reduction of } \\
\text { edema, attenuation of inflammatory measures }\end{array}$ & [52] \\
\hline Virgin olive oil & $\begin{array}{l}\text { Various in vitro and in vivo models of } \\
\text { inflammation; clinical trials in humans }\end{array}$ & The phenolic compound oleocanthal & $\begin{array}{l}\text { Reduction in cytokines, CRP, LTs, and PGs levels; inhibition of } \\
\text { COX, iNOS, 5-LOX and NFkB activity }\end{array}$ & [53] \\
\hline Medicinal plants & $\begin{array}{l}\text { Various in vitro and in vivo models } \\
\text { of inflammation }\end{array}$ & $\begin{array}{l}\text { Whole plant or parts; alkaloids, glycosides, } \\
\text { essential oils, fatty acids, flavonoids, nyctanthic } \\
\text { acid, phyllanthin, and many others }\end{array}$ & Analgesic effects and reduction of inflammatory measures & [54] \\
\hline Mangrove plants & $\begin{array}{l}\text { Various in vitro and in vivo models } \\
\text { of inflammation }\end{array}$ & $\begin{array}{l}\text { Various extracts, pure compounds such as: } \\
\text { agallochaol O, eugenol, mimosol D, calophyllolide }\end{array}$ & $\begin{array}{l}\text { Reduction in cytokines, LTs, NO and PGs levels; inhibition of } \\
\text { COX, iNOS, 5-LOX and NFkB activity }\end{array}$ & [55] \\
\hline Herbal plants & $\begin{array}{l}\text { Various in vitro and in vivo models } \\
\text { of inflammation }\end{array}$ & Various extracts, plants parts, resins & $\begin{array}{l}\text { Significant reduction in cytokines, LTs, NO and PGs levels; } \\
\text { inhibition of COX, iNOS and 5-LOX activity }\end{array}$ & [56] \\
\hline $\begin{array}{l}\text { Marine natural products } \\
\text { from soft corals }\end{array}$ & $\begin{array}{l}\text { Various in vitro and in vivo models } \\
\text { of inflammation (e.g., LPS-induced } \\
\text { inflammation) }\end{array}$ & $\begin{array}{l}\text { Sesquiterpenoids, diterpenoids, steroids, ceramide, } \\
\text { cerebrosides, and many others (a comprehensive } \\
\text { review with } 339 \text { structures) }\end{array}$ & $\begin{array}{l}\text { Reduction in cytokines, NO and PGs levels; inhibition of COX } \\
\text { and iNOS activity }\end{array}$ & [57] \\
\hline $\begin{array}{l}\text { Marine natural products } \\
\text { of algal origin }\end{array}$ & $\begin{array}{l}\text { Various in vitro and in vivo models of } \\
\text { inflammation (e.g., LPS-induced } \\
\text { inflammation) }\end{array}$ & $\begin{array}{l}\text { Various extracts and pure compounds such as } \\
\text { neorogioltriol, (12Z)-cis-maneonene-D }\end{array}$ & $\begin{array}{l}\text { Reduction in IL-6, TNF- } \alpha \text {, NO and PGs levels; inhibition of } \\
\text { COX, iNOS, NFאB and STAT activity }\end{array}$ & [58] \\
\hline Ethnobotanical plants & Carrageenan-induced paw edema & Various extracts & $\begin{array}{l}\text { Significant reduction in edema volume; effects were similar to } \\
\text { those of other anti-inflammatory drugs such as valdecoxib, } \\
\text { sulindac, aspirin, diclofenac, ibuprofen, phenylbutazone } \\
\text { and indomethacin }\end{array}$ & [59] \\
\hline
\end{tabular}


Table 1. Cont.

\begin{tabular}{|c|c|c|c|c|}
\hline $\begin{array}{l}\text { Main Theme of } \\
\text { the Article }\end{array}$ & Major Method(s) of Testing & Major Active Materials/Compounds & Main Effects on Inflammation * & Ref. \\
\hline $\begin{array}{l}\text { Plant-derived } \\
\text { compounds }\end{array}$ & $\begin{array}{l}\text { Various in vitro and in vivo models of } \\
\text { inflammation; pre-clinical tests and clinical } \\
\text { trials in humans }\end{array}$ & $\begin{array}{l}\text { Curcumin, colchicine, resveratrol, capsaicin, } \\
\text { epigallocatechin-3-gallate, quercetin }\end{array}$ & $\begin{array}{l}\text { Reduction in cytokines, LTs and PGs levels; inhibition of COX-2, } \\
\text { 5-LOX and NFkB activity; in humans: attenuation of } \\
\text { inflammatory measures such as CRP, IL-1 } \beta, \text { IL- } 6 \text {, and TNF- } \alpha\end{array}$ & [60] \\
\hline $\begin{array}{l}\text { Active organosulfur } \\
\text { compounds in garlic }\end{array}$ & $\begin{array}{l}\text { Various in vitro and in vivo animals } \\
\text { models (LPS-induced inflammation); } \\
\text { studies in human volunteers and } \\
\text { pre-clinical studies }\end{array}$ & $\begin{array}{l}\text { Ajoene, diallyl sulfide, diallyl disulfide, } \\
\text { allylmethyl sulfide, } S \text {-allyl cysteine, alliin, allicin }\end{array}$ & $\begin{array}{l}\text { Anti-inflammatory: reduction in PGs, NO, IL-1 } \beta \text {, IL6 and } \\
\text { TNF- } \alpha \text { levels; increase in IL-10 levels; inhibition of COX-2, } \\
\text { iNOS and NFKB activity Pro-inflammatory: opposite effects of } \\
\text { the mentioned above }\end{array}$ & [61] \\
\hline $\begin{array}{l}\text { Active organosulfur } \\
\text { compounds and extracts } \\
\text { of garlic }\end{array}$ & $\begin{array}{l}\text { Various in vitro and in vivo animals } \\
\text { models (e.g., LPS-induced inflammation); } \\
\text { studies in humans }\end{array}$ & $\begin{array}{l}\text { Aqueous, oil, chloroform and n-hexane extracts, as } \\
\text { well as compounds in previous raw }\end{array}$ & $\begin{array}{l}\text { Anti-inflammatory: reduction in IL-1 } \beta \text {, IL-6 and TNF- } \alpha \text { levels; } \\
\text { increase in IL-10 levels; inhibition of NFkB activity } \\
\text { Pro-inflammatory: increase in NO, IFN- } \gamma \text { and TNF- } \alpha \text { levels }\end{array}$ & [62] \\
\hline Indian medicinal plants & Various in vitro and in vivo models & $\begin{array}{l}\text { Polyphenols, lignans, anthraquinones, flavonoids, } \\
\text { alkaloids, terpenoids, saponins, polysaccharides }\end{array}$ & $\begin{array}{l}\text { Reduction in TNF- } \alpha \text { and other cytokines levels; inhibition of } \\
\text { PLA2 activity; general-anti-inflammatory, analgesic and } \\
\text { anti-allergic effects }\end{array}$ & [63] \\
\hline Marine diterpenoids & $\begin{array}{l}\text { Various in vitro and in vivo models } \\
\text { (e.g., LPS-induced inflammation) }\end{array}$ & $\begin{array}{l}\text { Eunicellane, briarane, cembrane and } \\
\text { other diterpenoids }\end{array}$ & $\begin{array}{l}\text { Significant reduction in IL-6, TNF- } \alpha \text {, NO, PGs and LTs levels; } \\
\text { significant inhibition of COX-2, iNOS, 5-LOX and NFKB activity, } \\
\text { some of the effects were comparable to those of } \\
\text { anti-inflammatory drugs such as indomethacin }\end{array}$ & [64] \\
\hline Citrus flavonoids & $\begin{array}{l}\text { Various in vitro and in vivo animal models } \\
\text { (e.g., LPS-induced inflammation), healthy } \\
\text { human volunteers }\end{array}$ & $\begin{array}{l}\text { Hesperidin and hesperetin—two major flavonoids } \\
\text { of citrus }\end{array}$ & $\begin{array}{l}\text { Reduction in IL-1 } \beta \text {, IL-6, TNF- } \alpha \text {, NO and PGs levels; inhibition } \\
\text { of COX-2, iNOS and NFKB activity; reduction in plasma CRP } \\
\text { levels in humans }\end{array}$ & [65] \\
\hline Plant polyphenols & $\begin{array}{l}\text { Various in vitro and in vivo animal models } \\
\text { (e.g., LPS-induced inflammation) }\end{array}$ & $\begin{array}{l}\text { Plant polyphenols such as curcumin, apigenin, } \\
\text { quercetin, E-cinnamaldehyde and E-resveratrol }\end{array}$ & $\begin{array}{l}\text { Reduction in IL-1 } \beta \text {, IL-6, TNF- } \alpha \text {, NO and PGs levels; inhibition } \\
\text { of COX-2, iNOS and NFKB activity }\end{array}$ & [66] \\
\hline Marine natural products & $\begin{array}{l}\text { Various in vitro and in vivo animal models } \\
\text { (e.g., LPS or carrageenan-induced } \\
\text { inflammation) }\end{array}$ & $\begin{array}{l}\text { Detailed structures of } 35 \text { marine compounds such } \\
\text { as steroids, fatty acids, diterpenes, } \\
\text { sesquiterpenoids, alkaloids and polysaccharides }\end{array}$ & $\begin{array}{l}\text { Significant reduction in IL-1 } \beta, \text { IL- } 6 \text {, TNF- } \alpha, \text { NO and PGs levels; } \\
\text { significant inhibition of COX-2, iNOS and NFkB activity }\end{array}$ & [67] \\
\hline Medicinal plants & $\begin{array}{l}\text { Various in vitro and in vivo animal models } \\
\text { (e.g., LPS-induced inflammation) }\end{array}$ & $\begin{array}{l}\text { Isogarcinol, andrograpanin, hinokitiol, } \\
\text { tectorigenin, } \alpha \text {-iso-cubebene, schisantherin A, } \\
\text { psoralidin, formosumone A, isofraxidin, maslinic } \\
\text { acid, mangiferin }\end{array}$ & $\begin{array}{l}\text { Reduction in IL-1 } \beta, \text { IL-6, TNF- } \alpha, \text { NO and PGs levels; inhibition } \\
\text { of COX- } 2 \text { and iNOS activity }\end{array}$ & [68] \\
\hline $\begin{array}{l}\text { Acacia catechu } \\
\text { (Mimosaceae); in most } \\
\text { reviewed studies } \\
\text { extracts of } A \text {. catechu } \\
\text { were combined with } \\
\text { extracts of } \\
\text { Scutellaria baicalensis }\end{array}$ & $\begin{array}{l}\text { LPS-induced inflammation in vitro (cell } \\
\text { lines and primary cells); arachidonic } \\
\text { acid-induced inflammation and edema in } \\
\text { mice ear; randomized, double-blind trial in } \\
\text { patients with osteoarthritis }\end{array}$ & Catethin, epicatechin, flavonoids & $\begin{array}{l}\text { In-vitro studies in cells-a mixture of A. catechu and } \\
\text { S. baicalensis significantly reduced mRNA levels of COX, IL-1 } 1 \beta \text {, } \\
\text { TNF- } \alpha \text { and IL-6, and decreased the activity of NF- } \mathrm{BB} \text { in } \\
\text { LPS-stimulated cells; ear edema in mice-a mixture of } \\
\text { A. catechu and S. baicalensis significantly attenuated COX and } \\
\text { 5-LOX activity in the ear; osteoarthritis patients-a blend of } \\
\text { A. catechu and S. baicalensis extracts ( } 500 \mathrm{mg} / \text { day) led to a } \\
\text { significant reduction in joint pain intensity (the effect was } \\
\text { stronger than that of naproxen } 440 \mathrm{mg} / \text { day) and, on the other } \\
\text { hand, significantly increased plasma levels of IL- } 1 \beta \text { and TNF- } \alpha\end{array}$ & [69] \\
\hline
\end{tabular}


Table 2. Summary of selected research articles reporting on the anti-inflammatory effects of plant products.

\begin{tabular}{|c|c|c|c|c|}
\hline Extracting Solvent(s) & Major Method(s) of Testing & Plant Species & Main Effects on Inflammation * & Ref. \\
\hline $80 \%$ EtOH in $\mathrm{H}_{2} \mathrm{O}$ & $\begin{array}{l}\text { Carrageenan-induced paw edema in rats (for } \\
\text { assessing inflammation) }\end{array}$ & 75 species of medicinal plants that grow in Italy & $\begin{array}{l}\text { Four species caused a significant reduction in paw edema similar to that } \\
\text { seen under treatment with indomethacin. Other species exerted a less } \\
\text { prominent edema-reducing effect }\end{array}$ & [70] \\
\hline $\mathrm{H}_{2} \mathrm{O}$ & Carrageenan-induced paw edema in rats & $\begin{array}{l}\text { Five species of Costa Rican medicinal plants: } \\
\text { Loasa speciciosa, Loasa triphylla, Urtica leptuphylla, } \\
\text { Urera baccifera, Chaptalia nutans }\end{array}$ & $\begin{array}{l}\text { Four species caused a significant reduction in paw edema, similar to that } \\
\text { seen under treatment with indomethacin }\end{array}$ & [71] \\
\hline $10 \%$ EtOH in $\mathrm{H}_{2} \mathrm{O}$ & $\begin{array}{l}\text { Hot-plate method for assessing analgesia; } \\
\text { carrageenan-induced paw edema }\end{array}$ & Portulaca oleracea L. subsp. sativa (Haw.) Celak & $\begin{array}{l}\text { A significant reduction in paw edema and an analgesic effect, similar to } \\
\text { that of diclofenac }\end{array}$ & [72] \\
\hline $\mathrm{H}_{2} \mathrm{O}$ & $\begin{array}{l}\text { LPS-induced inflammation in a macrophage } \\
\text { cell line (RAW } 264.7 \text { cells) }\end{array}$ & Portulaca oleracea $\mathrm{L}$. & $\begin{array}{l}\text { A significant reduction in IL-6, TNF- } \alpha, \text { NO and PGE2 levels; decrease in } \\
\text { iNOS expression; effects were more prominent than those of indomethacin }\end{array}$ & [73] \\
\hline $70 \% \mathrm{MeOH}$ in $\mathrm{H}_{2} \mathrm{O}$ & Carrageenan-induced paw edema in chicks & Portulaca oleracea $\mathrm{L}$. & $\begin{array}{l}\text { A significant dose-dependent reduction in paw edema which was stronger } \\
\text { than that seen under treatment with aspirin }\end{array}$ & [74] \\
\hline $\begin{array}{l}n \text {-Hexane, } \mathrm{CHCl}_{3} \\
\mathrm{MeOH}\end{array}$ & Croton oil-induced ear edema in mice & $\begin{array}{l}\text { Salvia officinalis } \mathrm{L} \text {. } \\
\text { (main active component is ursolic acid) }\end{array}$ & $\begin{array}{l}n \text {-Hexane and } \mathrm{CHCl}_{3} \text { extracts prominently reduced ear edema; } \\
\text { MeOH extract had a weak effect while the essential oil was ineffective; } \\
\text { the significant effect of ursolic acid was 2-fold stronger in reducing the } \\
\text { edema than indomethacin }\end{array}$ & [75] \\
\hline $\mathrm{H}_{2} \mathrm{O}, n-\mathrm{BuOH}$ & $\begin{array}{l}\text { Hot-plate method in mice; cotton pellet } \\
\text { granuloma and carrageenan-induced paw } \\
\text { edema in rats }\end{array}$ & Salvia officinalis $\mathrm{L}$. & $\begin{array}{l}\text { The } \mathrm{H}_{2} \mathrm{O} \text { and } \mathrm{BuOH} \text { extracts had a marked analgesic effect; both extracts } \\
\text { significantly and dose-dependently reduced pellet granuloma and paw } \\
\text { edema-effects were comparable to those of indomethacin }\end{array}$ & [76] \\
\hline $\begin{array}{l}\mathrm{CHCl}_{3}, \mathrm{MeOH} \\
\text { EtOAc, } n-\mathrm{BuOH}\end{array}$ & Carrageenan-induced paw edema in mice & Salvia fruticosa & $\begin{array}{l}\text { A significant reduction in paw edema similar to that seen under treatment } \\
\text { with diclofenac }\end{array}$ & [77] \\
\hline $\mathrm{H}_{2} \mathrm{O}$ & $\begin{array}{l}\text { Carrageenan-induced paw edema and } \\
\text { yeast-induced pyrexia in rats }\end{array}$ & Corchorus olitorius & $\begin{array}{l}\text { A significant reduction in paw edema which was stronger than that of } \\
\text { aspirin; attenuation of hyperthermia (fever) }\end{array}$ & [43] \\
\hline $\mathrm{EtOH}$ & $\begin{array}{l}\text { Carrageenan-induced paw edema and cotton } \\
\text { pellet-induced granuloma in rats }\end{array}$ & Carica papaya & $\begin{array}{l}\text { A significant reduction in paw edema and pellet granuloma; effects were } \\
\text { similar to those of indomethacin }\end{array}$ & [78] \\
\hline $\mathrm{MeOH}$ & $\begin{array}{l}\text { In-vitro assays for measuring neutrophils } \\
\text { inflammation and lipoxygenase activity }\end{array}$ & Vitex agnus-castus; 10 compounds were extracted & $\begin{array}{l}\text { Three compounds had a significant anti-inflammatory activity; } \\
\text { two compounds inhibited the activity of lipoxygenase }\end{array}$ & [79] \\
\hline Essential oils & LPS-induced inflammation in RAW 264.7 cells & Origanum ehrenbergii Boiss, Origanum syriacum L. & O. ehrenbergii caused a significant decrease in $\mathrm{NO}$ production & [80] \\
\hline $\mathrm{H}_{2} \mathrm{O}$ & $\begin{array}{l}\text { Ethyl phenylpropiolate and arachidonic } \\
\text { acid-induced ear edema, carrageenan-induced } \\
\text { paw edema, and cotton pellet-induced } \\
\text { granuloma in rats }\end{array}$ & Phyllanthus emblica Linn. & $\begin{array}{l}\text { Significant inhibition of ear inflammation and a reduction in paw edema } \\
\text { and pellet granuloma- effects were similar to those of aspirin; the extract } \\
\text { exerted an analgesic effect }\end{array}$ & [81] \\
\hline $\mathrm{MeOH}$ & LPS-induced inflammation in RAW 264.7 cells & $\begin{array}{l}\text { Citrus paradis, C. limon (L.) Bur, C. kotokan Hayata, } \\
\text { C. sinensis (L.) Osbec, C. reticulata Blanco, C. reticulata x } \\
\text { C. sinensis, C. tankan Hayata }\end{array}$ & $\begin{array}{l}\text { A significant, dose-dependent reduction in PGE2 and NO levels; a } \\
\text { significant decrease in COX-2 and iNOS expression }\end{array}$ & [82] \\
\hline $\mathrm{MeOH}$ & $\begin{array}{l}\text { Acetic acid-induced writhing in mice; } \\
\text { carrageenan-induced paw edema in rats }\end{array}$ & Mangifera indica & $\begin{array}{l}\text { A non-significant reduction in paw edema; a significant analgesic effect } \\
\text { similar to that of diclofenac }\end{array}$ & {$[44]$} \\
\hline $\mathrm{MeOH}$ & $\begin{array}{l}\text { Hot-plate method in mice; cotton pellet } \\
\text { granuloma and carrageenan-induced paw } \\
\text { edema in rats }\end{array}$ & Urginea indica Kunth & $\begin{array}{l}\text { Anti-inflammatory and analgesic effects, a significant reduction in paw } \\
\text { edema; effects were similar to those of ibuprofen }\end{array}$ & [83] \\
\hline
\end{tabular}


Table 2. Cont.

\begin{tabular}{|c|c|c|c|c|}
\hline Extracting Solvent(s) & Major Method(s) of Testing & Plant Species & Main Effects on Inflammation * & Ref. \\
\hline $\begin{array}{l}70 \% \mathrm{MeOH} \text { in } \mathrm{H}_{2} \mathrm{O} \text {, } \\
\text { then, in different } \\
\text { solvents }\end{array}$ & LPS-induced inflammation in RAW 264.7 cells & Crataegus pinnatifida Bunge var. typica Schneider & $\begin{array}{l}\text { The aqueous extract caused a significant reduction in NO levels; and, a } \\
\text { significant dose-dependent decrease in COX-2, IL-1 } \beta \text {, IL-6 and } \\
\text { TNF- } \alpha \text { expression }\end{array}$ & [45] \\
\hline $\mathrm{H}_{2} \mathrm{O}, \mathrm{EtOH}$ & $\begin{array}{l}\text { Inflammation induced by LPS and INF- } \gamma \text { in } \\
\text { RAW } 264.7 \text { cells }\end{array}$ & 40 Chinese plant species & Several extracts caused a significant reduction in NO and TNF- $\alpha$ levels & [84] \\
\hline $\mathrm{H}_{2} \mathrm{O}, \mathrm{EtOH}$ & $\begin{array}{l}\text { Inflammation induced by LPS and INF- } \gamma \text { in } \\
\text { J774A.1 cells }\end{array}$ & 13 Chinese plant species and two fungi & Some extracts caused a significant reduction in NO and TNF- $\alpha$ levels & [85] \\
\hline $\mathrm{EtOH}$ & Carrageenan-induced paw edema in rats & Desmodium gangeticum & A significant reduction in paw edema & [86] \\
\hline $\begin{array}{l}n \text {-Hexane, EtOAc, } \\
\mathrm{CHCl}_{3}, \mathrm{EtOH}\end{array}$ & $\begin{array}{l}\text { Cotton pellet granuloma and } \\
\text { carrageenan-induced paw edema in rats }\end{array}$ & $\begin{array}{l}\text { Vitex negundo Linn; only the ethanolic extract was } \\
\text { tested for biological activity }\end{array}$ & $\begin{array}{l}\text { A significant decrease in paw edema and a modest reduction in pellet } \\
\text { granuloma; effects were similar to those of indomethacin }\end{array}$ & {$[87]$} \\
\hline $\mathrm{EtOH}$ & Carrageenan-induced paw edema in rats & Sonerila tinnevelliensis Fischer & $\begin{array}{l}\text { A significant decrease in paw edema which was similar to that } \\
\text { of indomethacin }\end{array}$ & [88] \\
\hline $\mathrm{MeOH}$ & $\begin{array}{l}\text { Hot-plate test \& acetic acid-induced writhing } \\
\text { in mice; carrageenan-induced paw edema in } \\
\text { rats; yeast-induced pyrexia in rats }\end{array}$ & Mentha spicata L. & $\begin{array}{l}\text { Significant dose-dependent analgesic effect, anti-inflammatory effect } \\
\text { (reduction in paw edema) and antipyretic effect; effects were similar to } \\
\text { those of reference drugs such as ketorolac and paracetamol }\end{array}$ & [89] \\
\hline $\mathrm{H}_{2} \mathrm{O}$ & Carrageenan-induced paw edema in mice & Micromeria fruticosa & $\begin{array}{l}\text { A significant reduction in paw edema; effect was similar to that } \\
\text { of indomethacin }\end{array}$ & [46] \\
\hline $\mathrm{EtOH}$ & $\begin{array}{l}\text { 12-O-tetradecanoylphorbol-acetate-induced } \\
\text { ear edema in mice }\end{array}$ & Malva sylvestris $\mathrm{L}$ & $\begin{array}{l}\text { A significant dose-dependent reduction in ear edema; a decrease in IL-1 } \beta \\
\text { levels and leukocytes migration to the tissue; effects were less potent than } \\
\text { those of dexamethasone }\end{array}$ & [90] \\
\hline Extra virgin olive oil & $\begin{array}{l}\text { Acetic acid-induced writhing and formalin } \\
\text { tests in mice; carrageenan-induced paw edema } \\
\text { in rats }\end{array}$ & Olea europaea & $\begin{array}{l}\text { A significant analgesic effect similar to that of aspirin; a significant } \\
\text { reduction in paw edema similar to that seen under treatment } \\
\text { with dexamethasone }\end{array}$ & [91] \\
\hline $80 \% \mathrm{MOH}$ in $\mathrm{H}_{2} \mathrm{O}$ & Collagen-induced arthritis in mice & $\begin{array}{l}\text { Polyphenol extract of extra virgin olive oil } \\
\text { (Olea europaea) }\end{array}$ & $\begin{array}{l}\text { A significant reduction in joint edema and bone loss; a significant decline } \\
\text { in leukocytes migration; a decrease in PGE2, IL-1 } \beta \text {, IL-6 and TNF- } \alpha \text { levels; } \\
\text { a significant reduction in COX-2 expression and NFKB activity, among } \\
\text { other anti-inflammatory effects }\end{array}$ & [92] \\
\hline $\begin{array}{l}\text { EtOH and fractionation } \\
\text { with } n \text {-hexane, } \\
\mathrm{CHCl}_{3}, \text { EtOAc }\end{array}$ & $\begin{array}{l}\text { Aggregatibacter actinomycetemcomitans-induced } \\
\text { infection and inflammation in human oral cells } \\
\text { (in vitro model) }\end{array}$ & Malva sylvestris & $\begin{array}{l}\text { A significant reduction in protein levels of multiple pro-inflammatory } \\
\text { mediators (e.g., IL-1 } \beta, \text { IL-6, IL-8) and a decrease in their gene expression }\end{array}$ & [93] \\
\hline $\mathrm{EtOH}$ & $\begin{array}{l}\text { Assessment of 5-LOX activity in lung cancer } \\
\text { cell line A549 }\end{array}$ & Abutilon indicum $\mathrm{L}$. & A significant reduction in 5-LOX activity & [94] \\
\hline $\mathrm{EtOH}$ & Adjuvant-induced arthritis in mice & Citrus $x$ limon, Capsicum annuum $\mathrm{L}$. & $\begin{array}{l}\text { A significant decrease in CRP, IL- } 1 \beta \text {, IL- } 6 \text { and TNF- } \alpha \text { levels; a significant } \\
\text { reduction in arthritis }\end{array}$ & [95] \\
\hline Acetone & $\begin{array}{l}\text { LPS-induced inflammation in RAW } 264.7 \text { cells; } \\
\text { assessment of 15-LOX activity }\end{array}$ & 25 South African plant species & $\begin{array}{l}\text { A significant reduction in NO levels; significant inhibition of } \\
\text { 15-LOX activity }\end{array}$ & [96] \\
\hline $\mathrm{H}_{2} \mathrm{O}$ & Carrageenan-induced paw edema in mice & Morinda citrifolia $\mathrm{L}$. & $\begin{array}{l}\text { A significant reduction in TNF- } \alpha \text { levels; a significant decline in leukocytes } \\
\text { migration; effects were comparable to those of indomethacin }\end{array}$ & {$[97]$} \\
\hline
\end{tabular}


Table 2. Cont

\begin{tabular}{|c|c|c|c|c|}
\hline Extracting Solvent(s) & Major Method(s) of Testing & Plant Species & Main Effects on Inflammation * & Ref. \\
\hline $\begin{array}{l}\text { EtOH and fractionation } \\
\text { with } n \text {-hexane, } \\
\mathrm{CH}_{2} \mathrm{Cl}_{2} \text {, EtOAc }\end{array}$ & Carrageenan-induced paw edema in mice & Solanum lycocarpum A. St. Hil. & $\begin{array}{l}\text { A significant reduction in paw edema which was similar to that seen under } \\
\text { treatment with indomethacin }\end{array}$ & [98] \\
\hline $\begin{array}{l}\text { EtOH then } \\
\text { petroleum ether }\end{array}$ & $\begin{array}{l}\text { Human peripheral blood cells stimulated with } \\
\text { different antigens }\end{array}$ & $\begin{array}{l}\text { Azadirachta indica, Acacia catechu, Salmalia malabarica } \\
\text { (terpenoids were extracted) }\end{array}$ & $\begin{array}{l}\text { A significant dose-dependent reduction in NO levels; a decrease in } \\
\text { leukocytes count }\end{array}$ & [99] \\
\hline $\mathrm{MeOH}$ & $\begin{array}{l}\text { LPS-induced inflammation in RAW } 264.7 \text { cells; } \\
\text { dextran sulfate sodium-induced colitis in mice }\end{array}$ & Rosmarinus officinalis $\mathrm{L}$. & $\begin{array}{l}\text { A significant dose-dependent decrease in nitrites, IL- } 6 \text { and TNF- } \alpha \text { levels; } \\
\text { a significant reduction in COX-2 and iNOS expression; a significant decline } \\
\text { in NFkB activity, among other inflammatory markers that were attenuated }\end{array}$ & {$[100]$} \\
\hline $90 \% \mathrm{EtOH}$ in $\mathrm{H}_{2} \mathrm{O}$ & $\begin{array}{l}\text { LPS-induced inflammation in human } \\
\text { gingival fibroblasts }\end{array}$ & $\begin{array}{l}\text { Eriodictyon angustifolium, } 8 \text { active compounds } \\
\text { were extracted }\end{array}$ & A significant reduction in IL-6, IL-8 and MCP-1 levels & {$[101]$} \\
\hline $70 \% \mathrm{MeOH}$ in $\mathrm{H}_{2} \mathrm{O}$ & LPS-induced inflammation in RAW 264.7 cells & Drosera burmannii Vahl. (insectivorous herb, sundew) & $\begin{array}{l}\text { A significant dose-dependent decrease in nitrites and TNF- } \alpha \text { levels; a } \\
\text { significant dose-dependent reduction in COX-2 and iNOS expression }\end{array}$ & {$[102]$} \\
\hline $\begin{array}{l}n \text {-Hexane, } \mathrm{CH}_{2} \mathrm{Cl}_{2} \text {, } \\
\text { EtOAc, MeOH }\end{array}$ & $\begin{array}{l}\text { Carrageenan and experimental } \\
\text { trauma-induced paw edema in mice and rats }\end{array}$ & Ceratonia siliqua $\mathrm{L}$. & $\begin{array}{l}\text { A significant dose-dependent reduction in paw edema which was similar } \\
\text { to that seen under treatment with indomethacin }\end{array}$ & [103] \\
\hline $\mathrm{EtOH}$, acetone & LPS-induced release of TNF- $\alpha$ in THP- 1 cells & $\begin{array}{l}\text { Fourteen non-toxic extracts derived from six plants: } \\
\text { Cuphea carthagenensis (Lythraceae), } \\
\text { Echinodorus grandiflorus (Alismataceae), } \\
\text { Mansoa hirsuta (Bignoniaceae), Ouratea semiserrata } \\
\text { (Ochnaceae), Ouratea spectabilis and Remijia ferruginea } \\
\text { (Rubiaceae); three non-toxic active compounds were } \\
\text { extracted from O. semiserrata: epicatechin, } \\
\text { lanceoloside A and rutin }\end{array}$ & $\begin{array}{l}\text { Seven active extracts significantly reduced ( }>80 \% \text { inhibition) TNF- } \alpha \\
\text { production. The effects of the extracts were comparable to that of } \\
\text { dexamethasone }(0.1 \mu \mathrm{M}) \text {; epicatechin, lanceoloside A and rutin } \\
\text { significantly decreased the release of TNF- } \alpha \text { by approximately } 67 \%, 65 \% \\
\text { and } 42 \% \text {, respectively }\end{array}$ & [104] \\
\hline $\mathrm{CH}_{2} \mathrm{Cl}_{2}, \mathrm{EtOAc}, \mathrm{MeOH}$ & $\begin{array}{l}\text { Ear edema in mice; carrageenan-induced paw } \\
\text { edema in rats; acetic acid-induced abdominal } \\
\text { writhing and alteration of vascular } \\
\text { permeability in mice }\end{array}$ & Urera aurantiaca Wedd. (Urticaceae) & $\begin{array}{l}\text { A significant reduction in ear edema and myeloperoxidase activity in mice } \\
\text { and rats (effects were less potent than those of indomethacin); a significant } \\
\text { decrease in vascular permeability in mice (effect was comparable to that of } \\
\text { indomethacin); a significant anti-nociceptive effect in mice which was } \\
\text { comparable to that of indomethacin }\end{array}$ & [105] \\
\hline $\mathrm{MeOH}$ & LPS-induced inflammation in RAW 264 cells & Angelica acutiloba & $\begin{array}{l}\text { A significant decrease in NO, PGE2, IL- } 6 \text { and TNF- } \alpha \text { levels; a significant } \\
\text { increase in heme oxygenase-1 expression, suggesting enhanced } \\
\text { anti-inflammatory activity }\end{array}$ & [106] \\
\hline $\mathrm{H}_{2} \mathrm{O}, \mathrm{EtOH}$ & $\begin{array}{l}\text { A testosterone-induced benign prostatic } \\
\text { hyperplasia model in obese rats }\end{array}$ & Serenoa repens & A significant reduction in IL-1 $\beta$, IL-6, NO and TNF- $\alpha$ levels & [107] \\
\hline $\mathrm{EtOH}$ in $\mathrm{H}_{2} \mathrm{O}$ & $\begin{array}{l}\text { Formaldehyde and adjuvant-induced Arthritis } \\
\text { in rats }\end{array}$ & Picrorhiza kurroa & $\begin{array}{l}\text { A significant reduction in synovial expression of IL-1 } \beta, \text { IL- } 6 \text { and TNF- } \alpha \text {; a } \\
\text { significant decrease in paw edema; a significant decline in NO levels and } \\
\text { leukocytes infiltration to the inflamed joints; all the effects were } \\
\text { comparable to those of indomethacin }\end{array}$ & [108] \\
\hline
\end{tabular}

* In this table, the word "significant" indicates that the $P$ value for the difference between the tested groups is less than 0.05 or even smaller. 
Interestingly, M. fruticosa is one of the most useful herbs in western Asia, especially in the Middle East. Nevertheless, the specific compound(s) that is/are responsible for its anti-inflammatory activity is / are still unknown. Furthermore, M. sylvestris L. is an extensively eaten and widely used plant for medicinal purposes in the east Mediterranean region. A similar Micromeria species is M. nicaeenis. The chemical composition of this plant is unknown and, to the best of our knowledge, its anti-inflammatory activity has not been studied yet.

A study by Walker et al. [101] examined the anti-inflammatory properties of Eriodictyon angustifolium (a North American shrub) and its major active compounds on LPS-induced inflammation in human gingival fibroblasts. The dried leaves of the plant were extracted and the crude extracts were analyzed. Eight active compounds were identified as shown in Figure 4. Some of the extracts showed a profound anti-inflammatory activity. As mentioned above, aqueous extract of ripe carob (Ceratonia siliqua) is among the most used remedies in Arab traditional medicine [28]. A recent study by Lachkar et al. [103] clearly demonstrated that carob exerts prominent anti-inflammatory properties which are comparable to those of the potent anti-inflammatory drug indomethacin. Ripe pods of carob provide food for humans and animals. Ripe pods are traditionally extracted with boiling water after being crushed. The filtered extract is evaporated to viscous, sweet paste. In addition to its nutritional value, this paste has traditional, proven anti-inflammatory qualities, especially regarding mouth inflammations. Thus, it is strange that these qualities are just being studied in the last few years $[103,109,110]$.
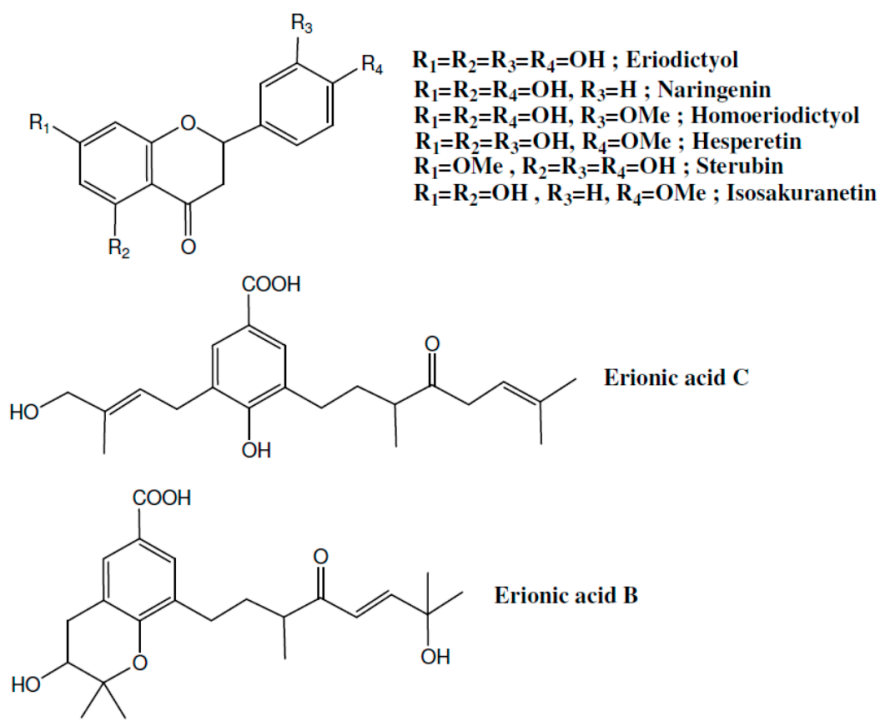

Figure 4. Structure of active anti-inflammatory compounds isolated from Eriodictyon angustifolium.

\section{Selected Reports of Single Natural Products with Anti-Inflammatory Activities}

As indicated in the previous section, isolation and testing of a single natural product for biological activities has both advantages and disadvantages. Two major advantages that were not mentioned are: (i) Testing a single active compound enables a thorough elucidation and better understanding of its mechanism of action; and (ii) if a single compound proves efficacious, it is possible to perform slight modifications on its structure or produce synthetic analogues in order to obtain more potent/efficacious compounds. In this regard, half of the the 2015 Nobel Prize in medicine was awarded to Campbell and Omura mainly for the synthesis and discovery of the anti-malarial compound ivermectin, which is the result of a very slight modification (a dihydro derivative) of the natural product avermectin [111].

Table 3 summarizes selected reports of anti-inflammatory activity of pure compounds that have been thoroughly investigated so far. An early study by Gupta et al. [112] reported that ursolic acid and cucurbitacin B did not exhibit anti-inflammatory properties. However, the findings concerning ursolic acid [112] are contradicted by later reports [50,75]. 
Table 3. Summary of selected reports of anti-inflammatory activity of pure compounds.

\begin{tabular}{|c|c|c|c|c|}
\hline Compound(s) & Major Method(s) of Testing & $\begin{array}{c}\text { Plants with High Concentration of } \\
\text { the Compound(s) }\end{array}$ & Main Effects on Inflammation & Ref. \\
\hline $\begin{array}{l}\text { Triterpenes: } \alpha / \beta \text {-amyrin } \\
\text { acetate, nimbin, filicene, } \\
\text { oleanolic acid }\end{array}$ & $\begin{array}{l}\text { Carrageenan and formaldehyde-induced paw } \\
\text { edema in rats }\end{array}$ & $\begin{array}{l}\text { Thymus serpyllum, } \\
\text { Syzygium aromaticum, Salvia triloba, } \\
\text { Rosmarinus officinalis, } \\
\text { Origanum majorana, } \\
\text { Ligustrum lucidum, Lavandula latifolia }\end{array}$ & $\begin{array}{l}\text { A significant reduction in edema volume; } \\
\text { effects were comparable to those } \\
\text { of hydrocortisone }\end{array}$ & [112] \\
\hline Quercetin & $\begin{array}{l}\text { Adjuvant and carrageenan-induced arthritis in rats } \\
\text { (acute and chronic designs) }\end{array}$ & $\begin{array}{l}\text { Allium cepa, Camellia sinensis, } \\
\text { Hypericum perforatum, } \\
\text { Podophyllum peltatum }\end{array}$ & $\begin{array}{l}\text { A significant reduction in edema volume both } \\
\text { in the acute and chronic models; effects were } \\
\text { comparable to those of phenylbutazone }\end{array}$ & [113] \\
\hline Allicin & Carrageenan-induced paw edema in rats & Allium sativum (garlic) & $\begin{array}{l}\text { A significant reduction in edema volume } \\
\text { which was similar to that of diclofenac }\end{array}$ & [114] \\
\hline (-)-Myrtenol & $\begin{array}{l}\text { Various models in mice: paw edema induced by } \\
\text { various compounds, and, carrageenan-induced } \\
\text { peritonitis (inflammation); acetic acid-induced } \\
\text { writhing, hot-plate test, and, paw licking induced by } \\
\text { formalin, glutamate, and capsaicin (nociception) }\end{array}$ & Tanacetum vulgare, Aralia cachemirica & $\begin{array}{l}\text { A significant reduction in edema volume } \\
\text { comparable to that of indomethacin; } \\
\text { a significant decrease in IL-1 } \beta \text { levels; } \\
\text { a significant decline in leukocytes count; } \\
\text { an significant analgesic effect which was } \\
\text { comparable to that of morphine in most tests }\end{array}$ & [115] \\
\hline $\begin{array}{l}\text { Various terpenes } \\
\text { and polyphenols }\end{array}$ & $\begin{array}{l}\text { Inflammation induced by LPS in bone marrow } \\
\text { derived dendritic cells }\end{array}$ & $\begin{array}{l}\text { Nepenthes mirabilis (Lour.) Rafarin } \\
\text { (Carnivorous plant) }\end{array}$ & $\begin{array}{l}\text { A significant reduction in IL-6, IL-12 and } \\
\text { TNF- } \alpha \text { levels }\end{array}$ & [116] \\
\hline Ferulic acid & $\begin{array}{l}\text { LPS-induced inflammation in macrophages } \\
\text { (in-vitro) }\end{array}$ & Solanum lycopersicum L. (Tomato) & $\begin{array}{l}\text { A significant decrease in IL- } 1 \beta \text { and TNF- } \alpha \\
\text { expression; a significant reduction in } \\
\text { NFKB activity }\end{array}$ & [117] \\
\hline 3-Hydroxyanthranilic acid & $\begin{array}{l}\text { LPS-induced inflammation in RAW } 264.7 \text { cells and } \\
\text { in mouse peritoneal macrophages }\end{array}$ & Hibiscus tilliaceus & $\begin{array}{l}\text { A significant decrease in NO, IL-1 } 1 \beta \text {, IL- } 6 \text { and } \\
\text { TNF- } \alpha \text { expression; a significant increase in } \\
\text { IL-10 expression; a significant reduction in } \\
\text { NFKB activity }\end{array}$ & [118] \\
\hline
\end{tabular}


Many studies have presented ursolic acid as one of the major compounds responsible for the anti-inflammatory activities of various plants [119,120]. Moreover, as seen in Figure 5, oleanolic acid (which possesses anti-inflammatory effects, Table 3) and ursolic acid are structural isomers with very small difference in their structures. As for cucurbitacin B, similarly, the findings of Gupta et al. [112] contradict later reports which clearly indicated that the anti-inflammatory activity of Ecballium elaterium (squirting cucumber) [121,122] and Cucurbita andreana [123] is mainly due to this compound.

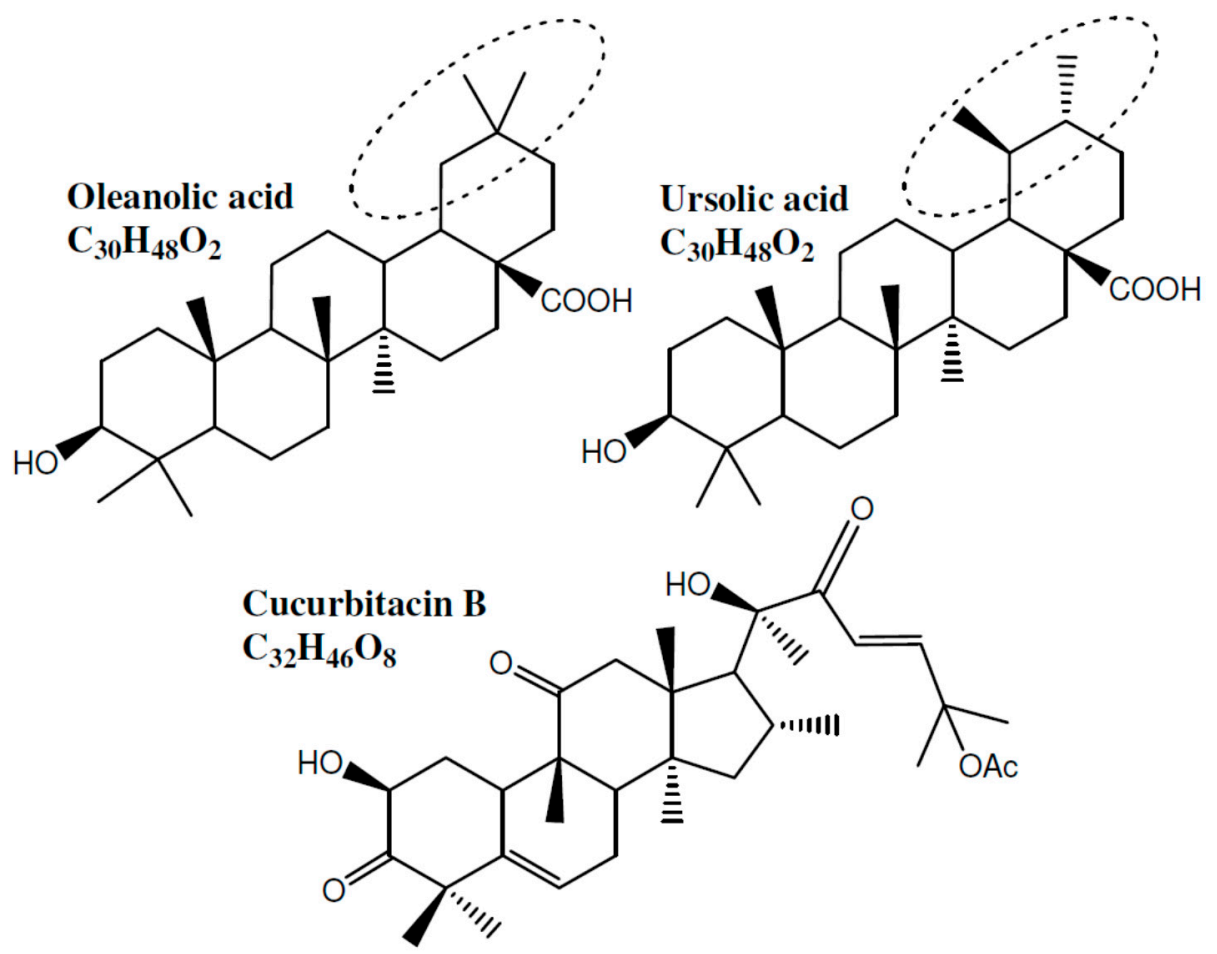

Figure 5. Structures of oleanolic acid, ursolic acid and cucurbitacin B.

In a study by Guardia et al. [113] three plant flavonoids—rutin, quercetin and hesperidin-were found to have anti-inflammatory effects. Quercetin is an abundant polyphenol in the plant kingdom. Its structure (with other compounds) is shown in Figure 6. Onions (Allium cepa) contain a high concentration of quercetin and studies confirmed the anti-inflammatory activities of onion juice and extracts [124]. Abutilon indicum also contains high amounts of quercetin and has significant anti-inflammatory activity [94]. Furthermore, garlic contains large amounts of allicin (the structure of which is shown in Figure 6) which exerts potent anti-inflammatory effects [114].<smiles>CC(C)(OCc1ccc(Cl)c(O)c1)Oc1oc2cc(O)cc(O)c2c(=O)c1O</smiles><smiles>C=CCS[S+]([O-])CC=C</smiles>

Figure 6. Structures of quercetin, allicin, (+)- $\alpha$-pinene and (-)-myrtenol.

As for the vast majority of natural products, even short term heating of garlic reduces the anti-inflammatory activity of allicin [125]. Another potent anti-inflammatory compound is 
(-)-myrtenol ([115], Table 3). As seen in Figure 6, it is essentially a mono-oxidized isomer of $(-)-\alpha$-pinene. Interestingly, the anti-inflammatory activity of $(-)-\alpha$-pinene is negligible compared with (+)- $\alpha$-pinene [126], while the anti-inflammatory activity of (+)-myrtenol was never reported. This "enantiomeric selectivity" does not always occur as reported for equal anti-inflammatory activities of the enantiomers shikonin and alkannin found in Alkanna tinctoria [127]. A study by Thao et al. [116] examined the anti-inflammatory properties of different terpenes and polyphenols. Twenty six compounds, some of which were novel, were isolated and tested in this research. The most active anti-inflammatory compound was a derivative of juglone (5-hydroxy-7-methyl-2methoxy-1,4-naphthaquinone). These results are consistent with previous reports regarding the anti-inflammatory activity of juglone [128].

\section{Concluding Remarks}

The data summarized in this article suggest that many compounds derived from natural products exert potent anti-inflammatory properties. Although the drugability of pure anti-inflammatory compounds extracted from natural products seems a complicated task, extracts and pure compounds of natural products may still open new venues for therapeutic interventions. Pharmaceutical companies will probably not express high interest and invest hugely in compounds that will be difficult to patent. Nevertheless, if proven efficacious and safe, the use of natural products-derived compounds should be advocated by policy makers and health authorities. Regular consumption of such products may become a successful and safe strategy to treat chronic inflammatory conditions.

Conflicts of Interest: The authors declare no conflict of interest.

\section{References}

1. Artis, D.; Spits, H. The biology of innate lymphoid cells. Nature 2015, 517, 293-301. [CrossRef] [PubMed]

2. Isailovic, N.; Daigo, K.; Mantovani, A.; Selmi, C. Interleukin-17 and innate immunity in infections and chronic inflammation. J. Autoimmun. 2015, 60, 1-11. [CrossRef] [PubMed]

3. Pedraza-Alva, G.; Pérez-Martínez, L.; Valdez-Hernández, L.; Meza-Sosa, K.F.; Ando-Kuri, M. Negative regulation of the inflammasome: Keeping inflammation under control. Immunol. Rev. 2015, 265, 231-257. [CrossRef] [PubMed]

4. Lucas, S.M.; Rothwell, N.J.; Gibson, R.M. The role of inflammation in CNS injury and disease. Br. J. Pharmacol. 2006, 147, S232-S240. [CrossRef] [PubMed]

5. Rock, K.L.; Lai, J.J.; Kono, H. Innate and adaptive immune responses to cell death. Immunol. Rev. 2011, 243, 191-205. [CrossRef] [PubMed]

6. Fernandes, J.V.; Cobucci, R.N.; Jatobá, C.A.; Fernandes, T.A.; de Azevedo, J.W.; de Araújo, J.M. The role of the mediators of inflammation in cancer development. Pathol. Oncol. Res. 2015, 21, 527-534. [CrossRef] [PubMed]

7. Heppner, F.L.; Ransohoff, R.M.; Becher, B. Immune attack: The role of inflammation in Alzheimer disease. Nat. Rev. Neurosci. 2015, 16, 358-372. [CrossRef] [PubMed]

8. Loane, D.J.; Kumar, A. Microglia in the TBI brain: The good, the bad, and the dysregulated. Exp. Neurol. 2016, 275, 316-327. [CrossRef] [PubMed]

9. Waisman, A.; Liblau, R.S.; Becher, B. Innate and adaptive immune responses in the CNS. Lancet Neurol. 2015, 14, 945-955. [CrossRef]

10. Vignali, D.A.; Kuchroo, V.K. IL-12 family cytokines: immunological playmakers. Nat. Immun. 2012, 13, 722-728. [CrossRef] [PubMed]

11. Montgomery, S.L.; Bowers, W.J. Tumor necrosis factor-alpha and the roles it plays in homeostatic and degenerative processes within the central nervous system. J. Neuroimmune. Pharmacol. 2012, 7, 42-59. [CrossRef] [PubMed]

12. Zelová, H.; Hošek, J. TNF- $\alpha$ signalling and inflammation: interactions between old acquaintances. Inflamm. Res. 2013, 62, 641-651. [CrossRef] [PubMed] 
13. Fenton, M.J. Review: Transcriptional and post-transcriptional regulation of interleukin 1 gene expression. Int. J. Immunopharmacol. 1992, 14, 401-411. [CrossRef]

14. Rider, P.; Carmi, Y.; Voronov, E.; Apte, R.N. Interleukin-1 $\alpha$. Semin. Immunol. 2013, 25, 430-438. [CrossRef] [PubMed]

15. Langrish, C.L.; McKenzie, B.S.; Wilson, N.J.; de Waal Malefyt, R.; Kastelein, R.A.; Cua, D.J. IL-12 and IL-23: master regulators of innate and adaptive immunity. Immunol. Rev. 2004, 202, 96-105. [CrossRef] [PubMed]

16. Duvallet, E.; Semerano, L.; Assier, E.; Falgarone, G.; Boissier, M.C. Interleukin-23: A key cytokine in inflammatory diseases. Ann. Med. 2011, 43, 503-511. [CrossRef] [PubMed]

17. Sabat, R. IL-10 family of cytokines. Cytokine Growth Factor Rev. 2010, 21, 315-324. [CrossRef] [PubMed]

18. Ng, T.H.; Britton, G.J.; Hill, E.V.; Verhagen, J.; Burton, B.R.; Wraith, D.C. Regulation of adaptive immunity; The role of interleukin-10. Front. Immunol. 2013, 31, 129. [CrossRef] [PubMed]

19. Kwilasz, A.J.; Grace, P.M.; Serbedzija, P.; Maier, S.F.; Watkins, L.R. The therapeutic potential of interleukin-10 in neuroimmune diseases. Neuropharmacology 2015, 96, 55-69. [CrossRef] [PubMed]

20. Goetzl, E.J.; An, S.; Smith, W.L. Specificity of expression and effects of eicosanoid mediators in normal physiology and human diseases. FASEB J. 1995, 9, 1051-1058. [PubMed]

21. Leff, J.A.; Busse, W.W.; Pearlman, D.; Bronsky, E.A.; Kemp, J.; Hendeles, L.; Dockhorn, R.; Kundu, S.; Zhang, J.; Seidenberg, B.C.; et al. Montelukast, a leukotriene-receptor antagonist, for the treatment of mild asthma and exercise-induced bronchoconstriction. N. Engl. J. Med. 1998, 339, 147-152. [CrossRef] [PubMed]

22. Peters-Golden, M.; Henderson, W.R. Leukotrienes. N. Engl. J. Med. 2007, 357, 1841-1854. [CrossRef] [PubMed]

23. Zhao, J.; Quyyumi, A.A.; Patel, R.; Zafari, A.M.; Veledar, E.; Onufrak, S.; Shallenberger, L.H.; Jones, L.; Vaccarino, V. Sex-specific association of depression and a haplotype in leukotriene A4 hydrolase gene. Psychosom. Med. 2009, 71, 691-696. [CrossRef] [PubMed]

24. Moncada, S.; Bolanos, J.P. Nitric oxide, cell bioenergetics and neurodegeneration. J. Neurochem. 2006, 97, 1676-1689. [CrossRef] [PubMed]

25. Rayet, B.; Gélinas, C. Aberrant rel/nfkb genes and activity in human cancer. Oncogene 1999, 18, 6938-6947. [CrossRef] [PubMed]

26. Oeckinghaus, A.; Hayden, M.S.; Ghosh, S. Crosstalk in NF-kB signaling pathways. Nat. Immunol. 2011, 12, 695-708. [CrossRef] [PubMed]

27. Ling, J.; Kumar, R. Crosstalk between NFkB and glucocorticoid signaling: A potential target of breast cancer therapy. Cancer Lett. 2012, 322, 119-126. [CrossRef] [PubMed]

28. Khalifa, A.B. Herbs: Nature's Pharmacy, 1st ed.; Arab Cultural Center: Casablanca, Morocco, 2004; pp. $286-288$.

29. Lindequist, U.; Niedermeyer, T.H.J.; Jülich, W.D. The pharmacological potential of mushrooms. Evid. Based Complement. Altern. Med. 2005, 2, 285-299. [CrossRef] [PubMed]

30. Elsayed, E.A.; El Enshasy, H.; Wadaan, M.A.M.; Aziz, R. Mushrooms: A potential natural source of anti-inflammatory compounds for medical applications. Mediat. Inflamm. 2014. [CrossRef] [PubMed]

31. Ngai, P.H.K.; Zhao, Z.; Ng, T.B. Agrocybin, an antifungal peptide from the edible mushroom Agrocybe cylindracea. Peptides 2005, 26, 191-196. [CrossRef] [PubMed]

32. Rosa, L.H.; Souza-Fagundes, E.M.; Machado, K.M.G.; Alves, T.M.A.; Martins-Filho, O.A.; Romanha, A.J.; Oliveira, R.C.; Rosa, C.A.; Zani, C.L. Cytotoxic, immunosuppressive and trypanocidal activities of agrocybin, a polyacetylene produced by Agrocybe perfecta (Basidiomycota). World J. Microb. Biot. 2006, 22, 539-545. [CrossRef]

33. U.S. National Library of Medicine, National Center for Biotechnology Information: Agrocybin (PubChem CID 11004). Available online: https://pubchem.ncbi.nlm.nih.gov/compound/Agrocybin\#section=Top (accessed on 30 September 2016).

34. Yaghoobi, R.; Kazerouni, A.; Kazerouni, O. Evidence for clinical use of honey in wound healing as an anti-bacterial, anti-inflammatory anti-oxidant and anti-viral agent: A review. Jundishapur J. Nat. Pharm. Prod. 2013, 8, 100-104. [CrossRef] [PubMed]

35. Vallianou, N.G.; Gounari, P.; Skourtis, A.; Panagos, J.; Kazazis, C. Honey and its anti-inflammatory, anti-bacterial and anti-oxidant properties. Gen. Med. 2014, 2. [CrossRef]

36. Deharo, E.; Ginsburg, H. Analysis of additivity and synergism in the anti-plasmodial effect of purified compounds from plant extracts. Malar. J. 2011, 10. [CrossRef] [PubMed] 
37. Umar, M.I.; Asmawi, M.Z.; Sadikun, A.; Abdul Majid, A.M.S.; Atangwho, I.J.; Ahamed, M.B.K.; Altaf, R.; Ahmad, A. Multi-constituent synergism is responsible for anti-inflammatory effect of Azadirachta indica leaf extract. Pharm. Biol. 2014, 52, 1411-1422. [CrossRef] [PubMed]

38. Hammer, K.D.; Hillwig, M.L.; Solco, A.K.; Dixon, P.M.; Delate, K.; Murphy, P.A.; Wurtele, E.S.; Birt, D.F. Inhibition of prostaglandin E2 production by anti-inflammatory Hypericum perforatum extracts and constituents in RAW 264.7 mouse macrophage cells. J. Agric. Food Chem. 2007, 55, 7323-7331. [CrossRef] [PubMed]

39. Perez, S.G.; Zavala, M.S.; Arias, L.G.; Ramos, M.L. Anti-inflammatory activity of some essential oils. J. Essent. Oil Res. 2011, 23, 38-44. [CrossRef]

40. Sharopov, F.; Braun, M.S.; Gulmurodov, I.; Khalifaev, D.; Isupov, S.; Wink, M. Antimicrobial, antioxidant, and anti-inflammatory activities of essential oils of selected aromatic plants from Tajikistan. Foods 2015, 4, 645-653. [CrossRef]

41. Nasri, S.; Anoush, M.; Khatami, N. Evaluation of analgesic and anti-inflammatory effects of fresh onion juice in experimental animals. Afr. J. Pharm. Pharmacol. 2012, 6, 1679-1684.

42. Jayanthi, M.K.; Dhar, M. Anti-inflammatory effects of Allium sativum (garlic) in experimental rats. Biomedicine 2011, 31, 84-89.

43. Zakaria, Z.A.; Sulaiman, M.R.; Arifah, A.K.; Mat Jais, A.M.; Somchit, M.N.; Kirisnaveni, K.; Punnitharrani, D.; Safarul, M.; Fatimah, C.A.; Johari, R. The anti-inflammatory and antipyretic activities of Corrchorus olotorius in rats. J. Pharm. Toxicol. 2006, 1, 139-146.

44. Islam, M.R.; Mannan, M.A.; Kabir, M.H.B.; Islam, A.; Olival, K.J. Analgesic, anti-inflammatory and antimicrobial effects of ethanol extracts of mango leaves. J. Bangladesh Agril. Univ. 2010, 8, 239-244. [CrossRef]

45. Li, C.; Wang, M.H. Anti-inflammatory effect of the water fraction from hawthorn fruit on LPS-stimulated RAW 264.7 cells. Nutr. Res. Pract. 2011, 5, 101-106. [CrossRef] [PubMed]

46. Abu-Gharbieh, E.; Shehab, N.G.; Khan, S.A. Anti-inflammatory and gastroprotective activities of the aqueous extract of Micromeria fruticosa (L.) Druce ssp Serpyllifolia in mice. Pak. J. Pharm. Sci. 2013, 26, 799-803. [PubMed]

47. Falcão, H.S.; Lima, I.O.; Santos, V.L.; Dantas, H.F.; Diniz, M.F.F.M.; Barbosa-Filho, J.M.; Batista, L.M. Review of the plants with anti-inflammatory activity studied in Brazil. Braz. J. Pharmacog. 2005, 15, 381-391. [CrossRef]

48. Watzl, B. Anti-inflammatory effects of plant-based foods and of their constituents. Int. J. Vitam. Nutr. Res. 2008, 78, 293-298. [CrossRef] [PubMed]

49. Aravindaram, K.; Yang, N.S. Anti-inflammatory plant natural products for cancer therapy. Planta Med. 2010, 76, 1103-1117. [CrossRef] [PubMed]

50. Arya, V.; Arya, M.L. A review on anti-inflammatory plant barks. Int. J. PharmTech Res. 2011, 3, 899-908.

51. Shah, B.N.; Seth, A.K.; Maheshwari, K.M. A review on medicinal plants as a source of anti-inflammatory agents. Res. J. Med. Plant. 2011, 5, 101-115. [CrossRef]

52. Beg, S.; Swain, S.; Hasan, H.; Abul Barkat, M.; Hussain, S. Systematic review of herbals as potential anti-inflammatory agents: Recent advances, current clinical status and future perspectives. Pharmacogn. Rev. 2011, 5, 120-137. [CrossRef] [PubMed]

53. Lucas, L.; Russell, A.; Keast, R. Molecular mechanisms of inflammation. Anti-inflammatory benefits of virgin olive oil and the phenolic compound oleocanthal. Curr. Pharm. Des. 2011, 17, 754-768. [CrossRef]

54. Sengupta, R.; Sheorey, S.D.; Hinge, M.A. Analgesic and anti-inflammatory plants: an updated review. Int. J. Pharm. Sci. Rev. Res. 2012, 12, 114-119.

55. Shilpi, J.A.; Islam, M.E.; Billah, M.; Islam, K.M.D.; Sabrin, F.; Uddin, S.J.; Nahar, L.; Sarker, S.D. Antinociceptive, anti-inflammatory, and antipyretic activity of mangrove plants: A mini review. Adv. Pharmacol. Sci. 2012, 576086. [CrossRef] [PubMed]

56. Kumar, S.; Bajwa, B.S.; Kuldeep, S.; Kalia, A.N. Anti-inflammatory activity of herbal plants: A review. Int. J. Adv. Pharm. Biol. Chem. 2013, 2, 272-281.

57. Wei, W.C.; Sung, P.J.; Duh, C.Y.; Chen, B.W.; Sheu, J.H.; Yang, N.S. Anti-inflammatory activities of natural products isolated from soft corals of Taiwan between 2008 and 2012. Mar. Drugs 2013, 11, 4083-4126. [CrossRef] [PubMed] 
58. Lee, J.C.; Hou, M.F.; Huang, H.W.; Chang, F.R.; Yeh, C.C.; Tang, J.Y.; Chang, H.W. Marine algal natural products with anti-oxidative, anti-inflammatory, and anti-cancer properties. Cancer Cell Int. 2013, 13. [CrossRef] [PubMed]

59. Bajpai, S.; Pathak, R.; Hussain, T. Anti-inflammatory activity of ethnobotanical plants used as traditional medicine: A review. Res. Rev. J. Bot.Sci. 2014, 3, 8-18.

60. Fürst, R.; Zündorf, I. Plant-derived anti-inflammatory compounds: Hopes and disappointments regarding the translation of preclinical knowledge into clinical progress. Mediat. Inflamm. 2014, 146832. [CrossRef] [PubMed]

61. Schäfer, G.; Kaschula, C.H. The immunomodulation and anti-Inflammatory effects of garlic organosulfur compounds in cancer chemoprevention. Anticancer Agents Med. Chem. 2014, 14, 233-240. [CrossRef] [PubMed]

62. Arreola, R.; Quintero-Fabián, S.; López-Roa, R.I.; Flores-Gutiérrez, E.O.; Reyes-Grajeda, J.P.; Carrera Quintanar, L.; Ortuño-Sahagún, D. Immunomodulation and anti-Inflammatory effects of garlic compounds. J. Immunol. Res. 2015. [CrossRef] [PubMed]

63. Bhagyasri, Y.; Lavakumar, V.; Divya Sree, M.S.; Ashok Kumar, C.K. An overview on anti-inflammatory activity of Indian herbal plants. Int. J. Res. Pharm. Nano Sci. 2015, 4, 1-9.

64. González, Y.; Torres-Mendoza, D.; Jones, G.E.; Fernandez, P.L. Marine diterpenoids a potential anti-inflammatory agents. Mediators Inflamm. 2015, 263543. [CrossRef] [PubMed]

65. Parhiz, H.; Roohbakhsh, A.; Soltani, F.; Ramin Rezaee, R.; Iranshahi, M. Antioxidant and anti-inflammatory properties of the citrus flavonoids hesperidin and hesperetin: An updated review of their molecular mechanisms and experimental models. Phytother. Res. 2015, 29, 323-331. [CrossRef] [PubMed]

66. Karunaweera1, N.; Raju, R.; Gyengesi, E.; Münch, G. Plant polyphenols as inhibitors of NF-kB induced cytokine production-A potential anti-inflammatory treatment for Alzheimer's disease? Front. Mol. Neurosci. 2015, 8. [CrossRef]

67. Cheung, R.C.F.; Ng, T.B.; Wong, J.H.; Chen, Y.; Chan, W.Y. Marine natural products with anti-inflammatory activity. Appl. Microbiol. Biotechnol. 2016, 100, 1645-1666. [CrossRef] [PubMed]

68. Maione, F.; Russo, R.; Khan, H.; Mascolo, N. Medicinal plants with anti-inflammatory activities. Nat. Prod. Res. 2016, 30, 1343-1353. [CrossRef] [PubMed]

69. Stohs, S.J.; Bagchi, D. Antioxidant, anti-inflammatory, and chemoprotective properties of Acacia catechu heartwood extracts. Phytother. Res. 2015, 29, 818-824. [CrossRef] [PubMed]

70. Mascolo, N.; Autore, G.; Capasso, F.; Menghini, A.; Fasulo, M.P. Biological screening of Italian medicinal plants for anti-inflammatory activity. Phytother. Res. 1987, 1, 28-31. [CrossRef]

71. Badilla, B.; Mora, G.; Poveda, L.J. Anti-inflammatory activity of aqueous extracts of five Costa Rican medicinal plants in Sprague-Dawley rats. Rev. Siol. Trop. 1999, 47, 723-727.

72. Chan, K.; Islam, M.W.; Kamil, M.; Radhakrishnan, R.; Zakaria, M.N.M.; Habibullah, M.; Attas, A. The analgesic and anti-inflammatory effects of Portulaca oleracea L. subsp. Sativa (Haw.) Celak. J. Ethnopharmacol. 2000, 73, 445-451. [CrossRef]

73. Kim, Y.O.; Lee, S.W.; Na, S.W.; Park, H.R.; Son, E.S. Anti-inflammatory effects of Portulaca oleracea L. on the LPS-induced RAW 264.7 cells. J. Med. Plants Res. 2015, 9, 407-411.

74. Agyare, C.; Baiden, E.; Apenteng, J.A.; Boakye, Y.D.; Adu-Amoah, L. Anti-infective and anti-inflammatory properties of Portulaca oleracea L. Donn. J. Med. Plnt. Res. 2015, 2, 2041-2064.

75. Baricevic, D.; Sosa, S.; Della Loggia, R.; Tubaro, A.; Simonovska, B.; Krasna, A.; Zupancic, A. Topical anti-inflammatory activity of Salvia officinalis L. leaves: the relevance of ursolic acid. J. Ethnopharmacol. 2001, 75, 125-132. [CrossRef]

76. Qnais, E.Y.; Abu-Dieyeh, M.; Abdulla, F.A.; Abdalla, S.S. The antinociceptive and anti-inflammatory effects of Salvia officinalis leaf aqueous and butanol extracts. Pharm. Biol. 2010, 48, 1149-1156. [CrossRef] [PubMed]

77. Boukhary, R.; Raafat, K.; Ghoneim, A.I.; Aboul-Ela, M.; El-Lakany, A. Anti-Inflammatory and antioxidant activities of Salvia fruticosa: An HPLC determination of phenolic contents. Evid. Based Complement. Altern. Med. 2016, 2016, 7178105.

78. Owoyele, B.V.; Adebukola, O.M.; Funmilayo, A.A.; Soladoye, A.O. Anti-inflammatory activities of ethanolic extract of Carica papaya leaves. Inflammopharmacology 2008, 16, 168-173. [CrossRef] [PubMed] 
79. Choudhary, M.I.; Jalil, A.S.; Nawaz, S.A.; Khan, K.M.; Tareen, R.B.; Atta-ur-Rahman. Antiinflammatory and lipoxygenase inhibitory compounds from Vitex agnus-castus. Phytother. Res. 2009, 23, 1336-1339. [CrossRef] [PubMed]

80. Loizzo, M.R.; Menichini, F.; Conforti, F.; Tundis, R.; Bonesi, M.; Saab, A.M.; Statti, G.A.; de Cindio, B.; Houghton, P.J.; Menichini, F.; et al. Chemical analysis, antioxidant, antiinflammatory and anticholinesterase activities of Origanum ehrenbergii Boiss and Origanum syriacum L. essential oils. Food Chem. 2009, 117, 174-180. [CrossRef]

81. Jaijoy, K.; Soonthornchareonnon, N.; Panthong, A.; Sireeratawong, S. Anti-inflammatory and analgesic activities of the water extract from the fruit of Phyllanthus emblica Linn. Int. J. Appl. Res. Nat. Prod. 2010, 3, 28-35.

82. Huang, Y.S.; Ho, S.C. Polymethoxy flavones are responsible for the anti-inflammatory activity of citrus fruit peel. Food Chem. 2010, 119, 868-873. [CrossRef]

83. Rahman, M.; Chowdhury, J.A.; Habib, R.; Saha, B.K.; Salauddin, A.D. Islam, M.K. Anti-inflammatory, anti-arthritic and analgesic activity of the alcoholic extract of the plant Urginea indica Kunth. Int. J. Pharm. Sci. Res. 2011, 2, 2915-2919.

84. Ravipati, A.S.; Zhang, L.; Koyyalamudi, S.R.; Jeong, S.J.; Reddy, N.; Bartlett, J.; Smith, P.T.; Shanmugam, K.; Münch, G.; Wu, M.J.; et al. Antioxidant and anti-inflammatory activities of selected Chinese medicinal plants and their relation with antioxidantcontent. BMC Complement. Altern. Med. 2012, 12. [CrossRef] [PubMed]

85. Diaz, P.; Jeong, S.C.; Lee, S.; Khoo, C.; Koyyalamudi, S.R. Antioxidant and anti-inflammatory activities of selected medicinal plants and fungi containing phenolic and flavonoid compounds. Chin. Med. 2012, 7. [CrossRef] [PubMed]

86. Yasmeen, N.; Sujatha, K. Evaluation of anti-inflammatory activity of ethanolic whole plant extract of Desmodium gangeticum L. Int. J. Phytomed. 2013, 5, 347-349.

87. Saravana, K.K.; Nagaveni, P.; Anitha, K.; Mahaboob, S.T.M. Evaluation of anti-inflammatory activity on Vitex negundo Linn. J. Drug Deliv. Ther. 2013, 3, 41-44.

88. Komalavalli, K.; Nithya, P.Y.; Sabapathy, M.; Mohan, V.R. Antiinflammatory activity of whole plant of Sonerila tinnevelliensis Fischer (Melastomataceae). Int. J. Pharmacol. Res. 2013, 3, 74-76.

89. Yousuf, P.H.; Noba, N.Y.; Shohel, M.; Bhattacherjee, R.; Das, B.K. Analgesic, anti-inflammatory and antipyretic effect of Mentha spicata (Spearmint). Br. J. Pharm. Res. 2013, 3, 854-864. [CrossRef]

90. Prudente, A.S.; Loddi, A.M.V.; Duarte, M.R.; Santos, A.R.S.; Pochapski, M.T.; Pizzolatti, M.G.; Hayashi, S.S.; Campos, F.R.; Pontarolo, R.; Fabio, A.; et al. Pre-clinical anti-inflammatory aspects of a cuisine and medicinal millennial herb: Malva sylvestris L. Food Chem. Toxicol. 2013, 58, 324-331. [CrossRef] [PubMed]

91. Fezai, M.; Senovilla, L.; Jemaà, M.; Ben-Attia, M. Analgesic, anti-Inflammatory and anticancer activities of extra virgin olive oil. J. Lipids 2013, 129736. [CrossRef] [PubMed]

92. Rosillo, M.A.; Alcaraz, M.J.; Sánchez-Hidalgo, M.; Fernández-Bolaños, J.G.; Alarcón-de-la-Lastra, C.; Ferrándiz, M.L. Anti-inflammatory and joint protective effects of extra-virgin olive-oil polyphenol extract in experimental arthritis. J. Nutr. Biochem. 2014, 25, 1275-1281. [CrossRef] [PubMed]

93. Benso, B.; Rosalen, P.L.; Severino Matias Alencar, S.M.; Murata, R.M. Malva sylvestris inhibits inflammatory response in oral human cells. An in vitro infection model. PLoS ONE 2015, 10. [CrossRef] [PubMed]

94. Kaladhar, D.S.V.G.K.; Swathi, S.K.; Varahalarao, V.; Nagendra, S.Y. Evaluation of anti-inflammatory and anti-proliferative activity of Abutilon indicum L. plant ethanolic leaf extract on lung cancer cell line A549 for system network studies. J. Cancer Sci. Ther. 2014, 6, 188-194.

95. Tag, H.M.; Kelany, O.E.; Tantawy, H.M.; Fahmy, A.A. Potential anti-inflammatory effect of lemon and hot pepper extracts on adjuvant-induced arthritis in mice. J. Basic Appl. Zoo. 2014, 67, 149-157. [CrossRef]

96. Adebayo, S.A.; Dzoyem, J.P.; Shai, L.J.; Eloff, J.N. The anti-inflammatory and antioxidant activity of 25 plant species used traditionally to treat pain in southern African. BMC Complement. Altern. Med. 2015, 15. [CrossRef] [PubMed]

97. Serafini, M.R.; de Oliveira Barreto, E.; de Almeida Brito, F.; Almeida dos Santos, J.P.; dos Santos Lima, B.; Banderó Walker, C.I.; Amaral da Silva, F.; Quintans-Junior, L.J.; Gelain, D.P.; de Souza Araújo, A.A. Anti-inflammatory property and redox profile of the leaves extract from Morinda citrifolia L. J. Med. Plants Res. 2015, 9, 693-701. 
98. Da Costa, G.A.; Morais, M.G.; Saldanha, A.A.; Assis Silva, I.C.; Aleixo, A.A.; Ferreira, J.M.; Soares, A.C.; Duarte-Almeida, J.M.; Lima, L.A. Antioxidant, antibacterial, cytotoxic, and anti-inflammatory potential of the leaves of Solanum lycocarpum A. St. Hil. (Solanaceae). Evid. Based Complement. Altern. Med. 2015, $2015,315987$.

99. Gupta, A.; Chaphalkar, S.R. Terpenoids from three medicinal plants and their potential anti-inflammatory and immunosuppressive activity on human whole blood and peripheral blood mononuclear cells. Asian J. Ethnopharmacol. Med. Foods 2016, 2, 13-17.

100. Medicherla, K.; Ketkar, A.; Sahu, B.D.; Sudhakar, G.; Sistla, R. Rosmarinus officinalis L. extract ameliorates intestinal inflammation through MAPKs/NF-KB signaling in a murine model of acute experimental colitis. Food Funct. 2016, 7, 3233-3243. [CrossRef] [PubMed]

101. Walker, J.; Reichelt, K.V.; Obst, K.; Widder, S.; Hans, J.; Krammer, G.E.; Ley, J.P.; Somoza, V. Identification of an anti-inflammatory potential of Eriodictyon angustifolium compounds in human gingival fibroblasts. Food Funct. 2016, 7, 3046-3055. [CrossRef] [PubMed]

102. Ghate, N.B.; Das, A.; Chaudhuri, D.; Panja, S.; Mandal, N. Sundew plant, a potential source of anti-inflammatory agents, selectively induces G2/M arrest and apoptosis in MCF-7 cells through upregulation of p53 and Bax/Bcl-2 ratio. Cell Death Discov. 2016, 2. [CrossRef] [PubMed]

103. Lachkar, N.; Al-Sobarry, M.; El Hajaji, H.; Lamkinsi, T.; Lachkar, M.; Cherrah, Y.; Alaoui, K. Anti-inflammatory and antioxidant effect of Ceratonia siliqua L. methanol barks extract. J. Chem. Pharm. Res. 2016, 8, 202-210.

104. Campana, P.R.; Mansur, D.S.; Gusman, G.S.; Ferreira, D.; Teixeira, M.M.; Braga, F.C. Anti-TNF- $\alpha$ activity of Brazilian medicinal plants and compounds from Ouratea semiserrata. Phytother. Res. 2015, 29, 1509-1515. [CrossRef] [PubMed]

105. Riedel, R.; Marrassini, C.; Anesini, C.; Gorzalczany, S. Anti-inflammatory and antinociceptive activity of Urera aurantiaca. Phytother. Res. 2015, 29, 59-66. [CrossRef] [PubMed]

106. Uto, T.; Tung, N.H.; Taniyama, R.; Miyanowaki, T.; Morinaga, O.; Shoyama, Y. Anti-inflammatory activity of constituents isolated from aerial part of Angelica acutiloba kitagawa. Phytother. Res. 2015, 29, 1956-1963. [CrossRef] [PubMed]

107. Iii Colado-Velázquez, J.; Mailloux-Salinas, P.; Medina-Contreras, J.; Cruz-Robles, D.; Bravo, G. Effect of Serenoa repens on oxidative stress, inflammatory and growth factors in obese Wistar rats with benign prostatic hyperplasia. Phytother. Res. 2015, 29, 1525-1531. [CrossRef] [PubMed]

108. Kumar, R.; Gupta, Y.K.; Singh, S.; Arunraja, S. Picrorhiza kurroa inhibits experimental arthritis through inhibition of pro-inflammatory cytokines, angiogenesis and MMPs. Phytother. Res. 2016, 30, 112-119. [CrossRef] [PubMed]

109. Rtibi, K.; Selmi, S.; Jabri, M.A.; Mamadou, G.; Limas-Nzouzi, N.; Sebai, H.; El-Benna, J.; Marzouki, L.; Eto, B.; Amri, M. Effects of aqueous extracts from Ceratonia siliqua L. pods on small intestinal motility in rats and jejunal permeability in mice. RSC Adv. 2016, 6, 44345-44353. [CrossRef]

110. Rtibi, K.; Jabri, M.A.; Selmi, S.; Sebai, H.; Amri, M.; El-Benna, J.; Marzouki, L. Ceratonia siliqua leaves exert a strong ROS scavenging effect in human neutrophils, inhibit myeloperoxydase in vitro and protect against intestinal fluid and electrolytes secretion in rats. RSC Adv. 2016, 6, 65483-65493. [CrossRef]

111. Campbell, W.C.; Fisher, M.H.; Stapley, E.O.; Albers-Schonberg, G.; Jacob, T.A. Ivermectin: A potent new antiparasitic agent. Science 1983, 221, 823-828. [CrossRef] [PubMed]

112. Gupta, M.B.; Bhalla, T.N.; Gupta, G.P.; Mitra, C.R.; Bhargava, K.P. Anti-inflammatory activity of natural products (I) Triterpenoids. Eur. J. Pharmacol. 1969, 6, 67-70. [CrossRef]

113. Guardia, T.; Rotelli, A.E.; Juarez, A.O.; Pelzer, L.E. Anti-inflammatory properties of plant flavonoids. Effects of rutin, quercetin and hesperidin on adjuvant arthritis in rat. Il Farmaco 2001, 56, 683-687. [CrossRef]

114. Bose, S.; Laha, B.; Banerjee, S. Anti-inflammatory activity of isolated allicin from garlic with post-acoustic waves and microwave radiation. J. Adv. Pharm. Edu. Res. 2013, 3, 512-515.

115. Silva, R.O.; Salvadori, M.S.; Sousa, F.B.M.; Santos, M.S.; Carvalho, N.S.; Sousa, D.P.; Gomes, B.S.; Oliveira, F.A.; Barbosa, A.L.R.; Freitas, R.M.; et al. Evaluation of the anti-inflammatory and antinociceptive effects of myrtenol, a plant-derived monoterpene alcohol, in mice. Flavour Fragr. J. 2014, 29, 184-192. [CrossRef]

116. Thao, N.P.; Luyen, B.T.T.; Koo, J.E.; Kim, S.; Koh, Y.S.; Thanh, N.V.; Cuong, N.X.; Kiem, P.V.; Minh, C.V.; Kim, H.Y. In vitro anti-inflammatory components isolated from the carnivorous plant Nepenthes mirabilis (Lour.) Rafarin. Pharm. Biol. 2016, 54, 588-594. [CrossRef] [PubMed] 
117. Navarrete, S.; Alarcón, M.; Palomo, I. Aqueous extract of tomato (Solanum lycopersicum L.) and ferulic acid reduce the expression of TNF- $\alpha$ and IL-1 $\beta$ in LPS-activated macrophages. Molecules 2015, 20, 15319-15329. [CrossRef] [PubMed]

118. Lee, K.; Kwak, J.H.; Pyo, S. Inhibition of LPS-induced inflammatory mediators by 3-hydroxyanthranilic acid in macrophages through suppression of PI3K/NF-KB signaling pathways. Food Funct. 2016, 7, 3073-3082. [CrossRef] [PubMed]

119. Aquino, R.; De Feo, V.; De Simone, F.; Pizza, C.; Cirino, C. Plant metabolites. New compounds and antiinflammatory activity of Uncaria tomentosa. J. Nat. Prod. 1991, 54, 453-459. [CrossRef] [PubMed]

120. Checker, R.; Sandur, S.K.; Sharma, D.; Patwardhan, R.S.; Jayakumar, S.; Kohli, V.; Sethi, G.; Aggarwal, B.B.; Sainis, K.B. Potent anti-inflammatory activity of ursolic acid, a triterpenoid antioxidant, is mediated through suppression of NF-kB, AP-1 and NF-AT. PLoS ONE 2012, 7. [CrossRef] [PubMed]

121. Yesilada, E.; Tanaka, S.; Sezik, E.; Tabata, M. Isolation of an anti-inflammatory principle from the juice of Ecballium elaterium. J. Nat. Prod. 1988, 51, 504-508. [CrossRef] [PubMed]

122. Yesilada, E.; Tanaka, S.; Tabata, M.; Sezik, E. Antiinflammatory effects of the fruit juice of Ecballium elaterium on edemas in mice. Phytother. Res. 1989, 3, 75-76. [CrossRef]

123. Jayaprakasam, B.; Seeram, N.P.; Nair, M.G. Anticancer and antiinflammatory activities of cucurbitacins from Cucurbita andreana. Cancer Lett. 2003, 189, 11-16. [CrossRef]

124. Oliveira, T.T.; Campos, K.M.; Cerqueira-Lima, A.T.; Brasil Carneiro, T.C.; da Silva Velozo, E.; Alexandrino Ribeiro Melo, I.C.; Abrantes Figueiredo, E.; de Jesus Oliveira, E.; Silva Amorim de Vasconcelos, D.F.; Pontes-de-Carvalho, L.C.; et al. Potential therapeutic effect of Allium cepa L. and quercetin in a murine model of Blomia Tropicalis induced asthma. DARU J. Pharm. Sci. 2015, 23. [CrossRef] [PubMed]

125. Shin, J.H.; Ryu, J.H.; Kang, M.J.; Hwang, C.R.; Han, J.; Kang, D. Short-term heating reduces the anti-inflammatory effects of fresh raw garlic extracts on the LPS-induced production of NO and pro-inflammatory cytokines by downregulating allicin activity in RAW 264.7 macrophages. Food Chem. Toxicol. 2013, 58, 545-551. [CrossRef] [PubMed]

126. Rufino, A.T.; Ribeiro, M.; Judas, F.; Salgueiro, L.; Lopes, M.C.; Cavaleiro, C.; Mendes, A.F. Anti-inflammatory and chondroprotective activity of (+)- $\alpha$-pinene: structural and enantiomeric selectivity. J. Nat. Prod. 2014, 77, 264-269. [CrossRef] [PubMed]

127. Tanaka, S.; Tajima, M.; Tsukada, M.; Tabata, M. A comparative study of anti-inflammatory activities of the enantiomers, shikonin and alkannin. J. Nat. Prod. 1986, 49, 466-469. [CrossRef] [PubMed]

128. Peng, X.; Nie, Y.; Wu, J.; Huang, Q.; Cheng, Y. Juglone prevents metabolic endotoxemia-induced hepatitis and neuroinflammation via suppressing TLR4/NF- $\mathrm{B}$ signaling pathway in high-fat diet rats. Biochem. Biophys. Res. Commun. 2015, 462, 245-250. [CrossRef] [PubMed]

(C) 2016 by the authors; licensee MDPI, Basel, Switzerland. This article is an open access article distributed under the terms and conditions of the Creative Commons Attribution (CC-BY) license (http://creativecommons.org/licenses/by/4.0/). 